\title{
Numerical simulation of hydrodynamics and bank erosion in a river bend
}

\author{
Massimo Rinaldi, ${ }^{1}$ Beatrice Mengoni, ${ }^{2}$ Laura Luppi, ${ }^{1}$ Stephen E. Darby, ${ }^{3}$ \\ and Erik Mosselman ${ }^{4}$ \\ Received 18 March 2008; revised 23 June 2008; accepted 10 July 2008; published 20 September 2008.
}

[1] We present an integrated analysis of bank erosion in a high-curvature bend of the gravel bed Cecina River (central Italy). Our analysis combines a model of fluvial bank erosion with groundwater flow and bank stability analyses to account for the influence of hydraulic erosion on mass failure processes, the key novel aspect being that the fluvial erosion model is parameterized using outputs from detailed hydrodynamic simulations. The results identify two mechanisms that explain how most bank retreat usually occurs after, rather than during, flood peaks. First, in the high curvature bend investigated here the maximum flow velocity core migrates away from the outer bank as flow discharge increases, reducing sidewall boundary shear stress and fluvial erosion at peak flow stages. Second, bank failure episodes are triggered by combinations of pore water and hydrostatic confining pressures induced in the period between the drawdown and rising phases of multipeaked flow events.

Citation: Rinaldi, M., B. Mengoni, L. Luppi, S. E. Darby, and E. Mosselman (2008), Numerical simulation of hydrodynamics and bank erosion in a river bend, Water Resour. Res., 44, W09428, doi:10.1029/2008WR007008.

\section{Introduction}

[2] Bank retreat is a key process in river morphodynamics affecting channel mobility, floodplain evolution and associated habitat development [e.g., Goodson et al., 2002]; causing damage to riparian lands and infrastructure [e.g., Simon, 1995]; and mobilizing sediments that can cause turbidity, nutrient, and contaminant problems [e.g., Bull, 1997; Reneau et al., 2004]. Reliable methods for predicting bank stability and retreat are therefore extremely important for providing assessments of the implications of these processes on river dynamics and management.

[3] Bank retreat involves a combination of processes, and much progress has recently been made in quantifying the two main sets, namely fluvial erosion and mass failure [Rinaldi and Darby, 2008]. For example, progress in quantifying fluvial erosion (i.e., the removal of bank material by the action of hydraulic forces) has included the development and application of specific techniques for measuring in situ the erodibility parameters of the bank sediments [Tolhurst et al., 1999; Hanson and Simon, 2001; Wynn and Mostaghimi, 2006; Clark and Wynn, 2007], as well as methods to model the near-bank flow field using computational fluid dynamics (CFD) and other techniques [Darby et al., 2004; Kean and Smith, 2006a, 2006b; McBride et al., 2007; Julian and Torres, 2006; Papanicolaou et al., 2007]. With respect to mass failure, recent studies have focused on two main topics:

\footnotetext{
${ }^{1}$ Department of Civil and Environmental Engineering, University of Florence, Florence, Italy.

${ }^{2}$ Centre of Research and Advanced Education for Hydrogeological Risk Prevention, Retignano, Italy.

${ }^{3}$ School of Geography, University of Southampton, Southampton, UK.

${ }^{4}$ Deltares and Delft University of Technology, Delft, Netherlands.
}

Copyright 2008 by the American Geophysical Union. 0043-1397/08/2008WR007008\$09.00
(1) accounting for the effects of positive and negative pore water pressures and confining river pressures [Casagli et al., 1999; Simon et al., 2000; Rinaldi et al., 2004]; and (2) quantification of the effects of riparian vegetation on bank stability [Simon and Collison, 2002; Pollen and Simon, 2005; Pollen, 2006; Van De Wiel and Darby, 2007]. Progress has also been made in understanding and quantifying the effects of seepage erosion on mass failures [Fox et al., 2006, 2007; Wilson et al., 2007].

[4] Although all these advances are significant, it is noteworthy that these studies each focus on a single set of processes. In contrast, relatively few attempts have been made to model the combined effects of interacting bank erosion processes [e.g., Simon et al., 2003, 2006; Darby et al., 2007]. Of these studies the one by Darby et al. [2007], who developed a simulation modeling approach in which hydraulic erosion, finite element seepage, and limit equilibrium stability analyses are fully coupled, is perhaps the most detailed. Nevertheless, a key remaining limitation, as recognized by those authors, is that the procedure they used to calculate the near-bank shear stresses governing fluvial erosion was a gross idealization.

[5] In this paper we build on the framework for the simulation of bank processes identified by Darby et al. [2007] but make further progress by utilizing a more advanced hydrodynamic model to simulate the reach-scale hydraulics within a river bend, in order to account for the spatial pattern and temporal variability of shear stress and resulting impacts on bank stability. The objectives of this paper can therefore be summarized as follows: (1) to make a further development of the simulation approach proposed by Darby et al. [2007] by coupling groundwater flow and stability modeling at the scale of a single bank with detailed hydrodynamic modeling at the reach scale in a channel bend; (2) to investigate how temporal changes in hydrody- 

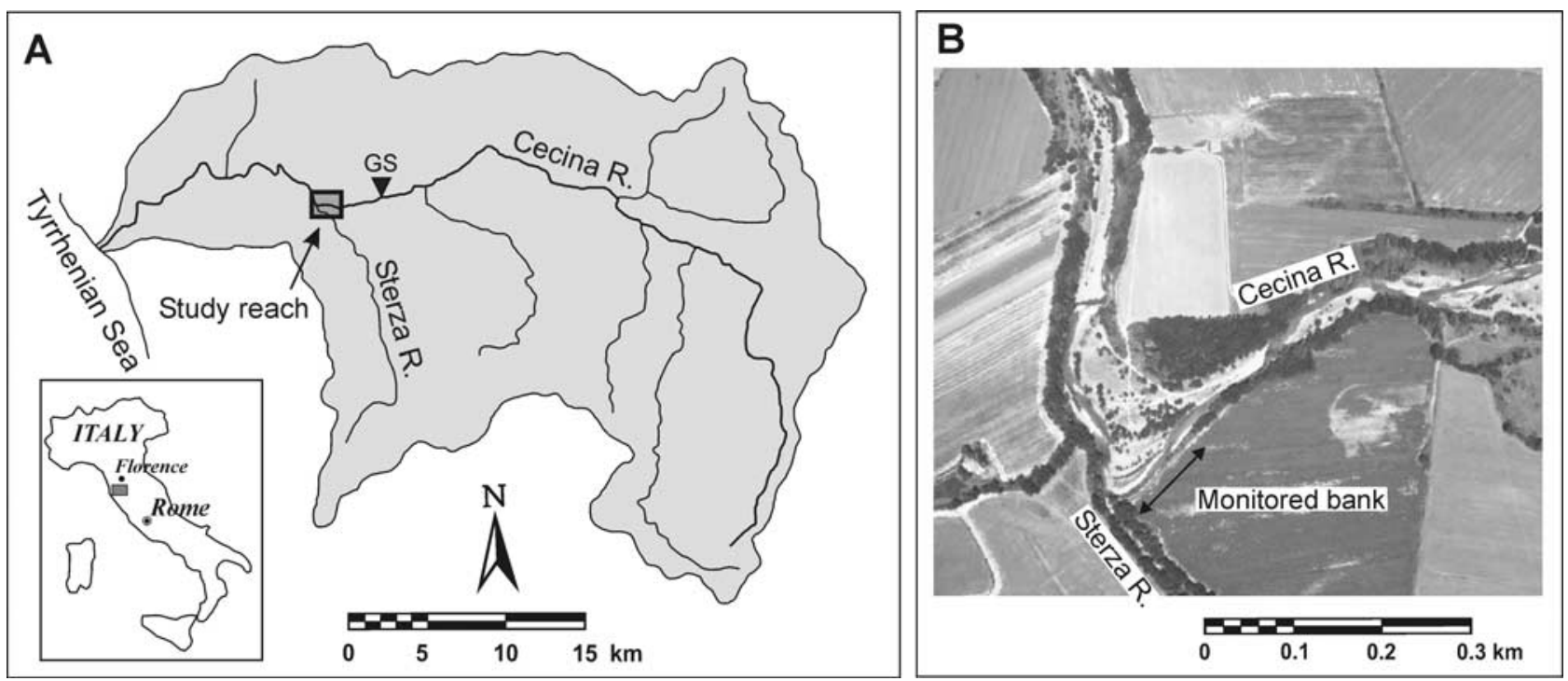

Figure 1. Cecina River study reach. (a) Cecina basin and location of the study reach (GS, gauging station of Ponte di Monterufoli). (b) An 2004 aerial photograph (1:10,000 scale) showing the study reach and monitored bank (aerial photograph reproduced by permission of Provincia di Pisa).

namic patterns occurring during a flow event hydrograph can influence bank stability processes; (3) to investigate and quantify the role of fluvial erosion, driven by hydrodynamic conditions at the reach scale, versus mass failure, driven by geotechnical factors (i.e., changes in shear strength due to variable pore water pressure conditions) at the local scale.

\section{Study Site Description}

[6] The study site is located along the Cecina River (Tuscany, central Italy). The catchment (drainage area of about $905 \mathrm{~km}^{2}$ ) (Figure 1a) is dominated by hilly slopes constituted of erodible Pliocene marine sediments (sand and clay), with relatively low relief, and Mediterranean climatic conditions characterized by high variability in flow discharges and flashy floods. The study site is located in the middle reaches of the basin, about $2 \mathrm{~km}$ downstream of the Ponte di Monterufoli gauging station $\left(634 \mathrm{~km}^{2}\right)$, where the mean daily discharge is $7.61 \mathrm{~m}^{3} \mathrm{~s}^{-1}$, but the peak discharge with a 2 year return period $\left(Q_{2}\right)$ is $322 \mathrm{~m}^{3} \mathrm{~s}^{-1}$. The study reach encompasses within it the confluence with the Sterza River $\left(110 \mathrm{~km}^{2}\right)$, though the confluence is located immediately downstream of the eroding bank that is the main focus of this study. Bed material in the study reach is composed of gravel and the average channel gradient is 0.0021 . The eroding bank in the study reach is about $80 \mathrm{~m}$ long, located along the outer side of a sharp bend having a curvature $r_{c} / w=1.6$ (where $r_{c}$ is the centerline radius and $w$ is the mean channel width of the reach) (Figure 1b).

[7] This particular site was selected for the following reasons: (1) the presence of an actively eroding bank along a curved channel reach; (2) the similarity of the bank characteristics (see below) to those observed at many other sites along the same river and similar rivers in the region; and (3) the location of the study site close to a gauging station, ensuring the availability of measured river stage and flow discharge data. The eroding bank has an average height of about 5.0 to $5.5 \mathrm{~m}$. Bank materials within the study reach are quite variable in their composition and thickness, but the general stratigraphy can be described as follows (from the base to the top): (1) a wedge of loose gravel and cobble at the bank toe; (2) a layer of in situ packed and slightly cemented gravel (thickness ranging from 185 to $225 \mathrm{~cm}$ ); (3) alternating sheets and lenses of silt, sand, and clay (with a thickness ranging from 80 to $120 \mathrm{~cm}$ ); (4) a massive sandy silt (with a thickness of $85-165 \mathrm{~cm}$ ), and; (5) a top layer of sandy silt, pedogenized, and with root traces (thickness of $110-155 \mathrm{~cm})$.

[8] Within the study reach, various monitoring activities were carried out during the period October 2003 to May 2004. A detailed description of these activities, together with a discussion of the overall results, is reported by Luppi et al. [2008]. For the purposes of this paper we focus on the first monitoring period, between October and December 2003. Bank retreat during this period was monitored by periodic topographic surveys, combined with a network of vertical pins at a total of 27 sections distributed along the bank top for prompt baseline resurvey using perpendicular offsets [Lawler, 1993] immediately after each flow event, and horizontal erosion pins along 6 representative bank profiles. Bank retreat observed during the study period is reported in Figure 2. Hydrological parameters were measured by installing a monitoring station along the upstream, stable, portion of the bank, where 15 -min resolution measurements of river stage (by a river stage sensor), and water table (by two piezometers) were collected using a data logger. Additionally, 11 crest gauges were installed along the monitored reach to measure the water level profile at the peak of erosive flow events. River stage, rainfall and flow discharge, all collected at the same 15-min resolution, were also available at the Ponte di Monterufoli gauging station ( $2 \mathrm{~km}$ upstream, but with no significant additional runoff sources in the intervening reach).

\section{Methods}

[9] In the previous study by Darby et al. [2007], fluvial erosion, groundwater flow, and limit equilibrium models for 


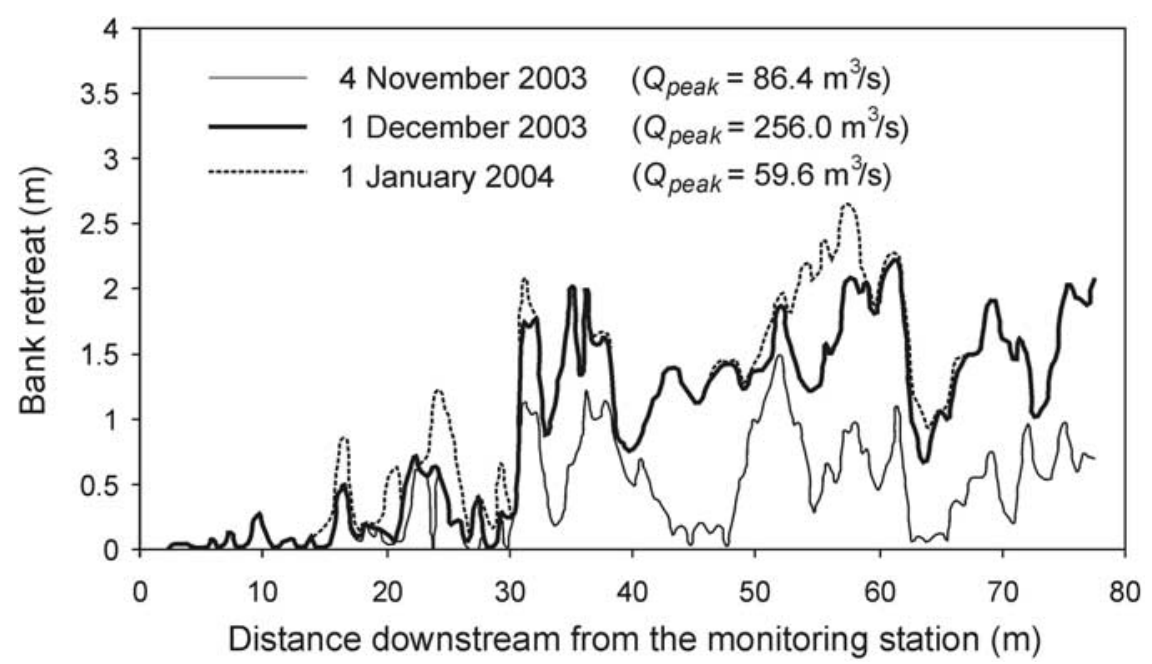

Figure 2. Total bank retreat monitored on the outer bank of the study reach during the three investigated flow events.

bank stability were coupled to simulate bank erosion. In this paper, further progress is made by using hydrodynamic simulations to determine the flow field along the reach, and to define the near-bank shear stresses used in the fluvial erosion model more accurately. The combined modeling can be described in two phases: (1) hydrodynamic modeling (we used a 2-D depth-averaged hydrodynamic model to calculate the near-bank shear stresses required for the fluvial erosion model) and (2) bank dynamic modeling. This phase involves the application and combination of three submodels for (1) fluvial erosion, to quantify the bank toe deformation due to the hydraulic action; (2) groundwater flow, to define changes in pore water pressure distribution within the bank due to varying river stages and rainfall; and (3) bank stability, to determine the occurrence of mass failures in the upper cohesive portion of the bank due to changes in geometry induced by fluvial toe erosion or changes in shear strength induced by varying pore water pressures.

[10] It is important to remark that all the model components are applied at each of a series of discrete time steps throughout a specific flow event hydrograph. To our knowledge, this is the first attempt to couple hydrodynamic simulations with these three relevant bank process submodels. In this section, the different model components and their parameterization are described in detail.

\subsection{Hydrodynamic Model}

[11] We simulated the hydrodynamics of the study reach using a version of the software DELFT3D (developed by WL | Delft Hydraulics and Delft University of Technology) that employs a 2-D depth-averaged hydrodynamic numerical model with a fixed, orthogonal-curvilinear, boundary fitted grid. The use of a 2-D approach was considered suitable here because the Cecina is relatively wide and shallow, and the flow field is mainly developed in the horizontal direction. Of course the 2-D representation has some limitations with respect to alternative, 3-D, approaches. In particular it cannot completely describe the threedimensional effects of the river bend geometry on the flow velocity distribution, nor are three-dimensional flow structures that are likely present in the near bank zone accounted for. However, the 2-D numerical model accounts for the effects of the secondary flow on the main flow field by employing an extra parametric equation [WL Delft Hydraulics, 2006], whereas the presence of 3-D flow structures in the near bank zone are less significant during higher flow discharges, for reasons described below. The use of a fixed bed is another limitation, given that bed deformation may have occurred during the flow events. We discuss this point further below.

[12] The model employed here solves the depth-averaged unsteady water flow equations. The equation system consists of the horizontal momentum equations, the continuity equation, and a turbulence closure model. The equations are solved on an orthogonal curvilinear grid, but for clarity only equations for a Cartesian rectangular grid are given here. The horizontal momentum equations read

$$
\begin{gathered}
\frac{\partial h U}{\partial t}+\frac{\partial h U^{2}}{\partial x}+\frac{\partial U V}{\partial y}=-\frac{\tau_{x}}{\rho}-g h \frac{\partial \varsigma}{\partial x}+h F_{s x} \\
\frac{\partial h V}{\partial t}+\frac{\partial h U V}{\partial x}+\frac{\partial h V^{2}}{\partial y}=-\frac{\tau_{y}}{\rho}-g h \frac{\partial \varsigma}{\partial Y}+h F_{s y}
\end{gathered}
$$

where $h=\left(\varsigma-z_{b}\right)$ is the water depth $(\mathrm{m}) ; z_{b}(\mathrm{~m})$ is the bed elevation; $\varsigma(\mathrm{m})$ is the water level with respect to the reference level; $\tau_{x}\left(\mathrm{~N} \mathrm{~m}^{-2}\right)$ and $\tau_{y}\left(\mathrm{~N} \mathrm{~m}^{-2}\right)$ are the shear stress components; $F_{s x}\left(\mathrm{~m} \mathrm{~s}^{-2}\right)$ and $F_{s y}\left(\mathrm{~m} \mathrm{~s}^{-2}\right)$ are the correction terms for the secondary flow; $g\left(\mathrm{~m} \mathrm{~s}^{-2}\right)$ is the gravitational acceleration; $U\left(\mathrm{~m} \mathrm{~s}^{-1}\right)$ is the depth-averaged velocity component in the $x$ direction; and $V\left(\mathrm{~m} \mathrm{~s}^{-1}\right)$ is the depth-averaged velocity component in the $y$ direction.

[13] The shear stress components $\tau_{x}$ and $\tau_{y}$ are modeled using the Chézy roughness coefficient, $C\left(\mathrm{~m}^{1 / 2} \mathrm{~s}^{-1}\right)$, as

$$
\begin{gathered}
\tau_{x}=\frac{\rho g U \sqrt{U^{2}+V^{2}}}{C^{2}} \\
\tau_{y}=\frac{\rho g V \sqrt{U^{2}+V^{2}}}{C^{2}}
\end{gathered}
$$




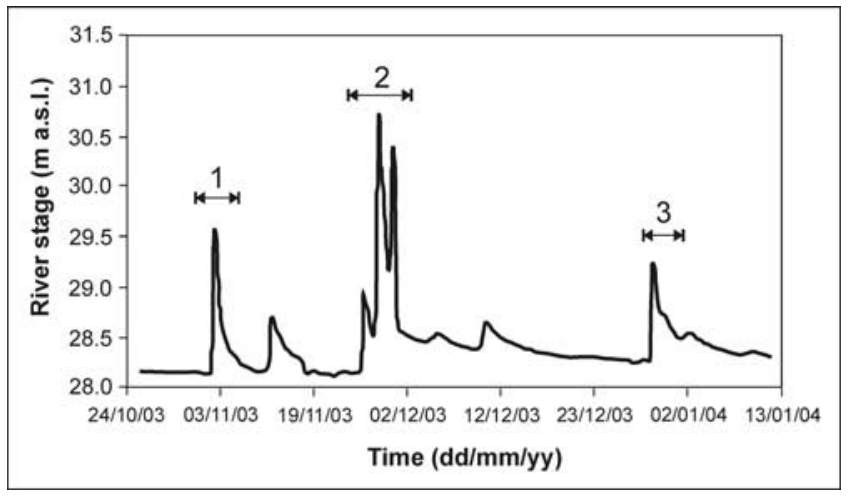

Figure 3. River stages during the period of investigation showing the three simulated events: 1, flow event $1-4$ November $2003\left(Q_{\text {peak }}=86.4 \mathrm{~m}^{3} \mathrm{~s}^{-1}\right) ; 2$, flow event 24 November to 1 December $2003\left(Q_{\text {peak }}=256.0 \mathrm{~m}^{3} \mathrm{~s}^{-1}\right) ; 3$, flow event 29 December 2003 to 1 January $2004\left(Q_{\text {peak }}=\right.$ $59.6 \mathrm{~m}^{3} \mathrm{~s}^{-1}$ ).

where $\rho$ is the density of water (taken here as $1000 \mathrm{~kg} \mathrm{~m}^{-3}$ ).

[14] The effect of secondary flow on the depth-averaged momentum equations is accounted for by the correction terms $\left(F_{s x}\right.$ and $\left.F_{s y}\right)$ which are calculated here as follows:

$$
\begin{gathered}
F_{s x}=\frac{1}{h}\left(-2 \frac{\partial \beta h U V}{\partial x}+\frac{\partial \beta h\left(U^{2}+V^{2}\right)}{\partial y}\right) \\
F_{s y}=\frac{1}{h}\left(2 \frac{\partial \beta h U V}{\partial y}+\frac{\partial \beta h\left(U^{2}+V^{2}\right)}{\partial x}\right)
\end{gathered}
$$

[15] The nondimensional parameter $\beta$ is given by the following relation (for further details, see $W L \mid$ Delft Hydraulics [2006]):

$$
\beta=\beta_{c}\left(5 \alpha-15.6 \alpha^{2}+37.5 \alpha^{3}\right) \frac{h}{R_{s}}
$$

in which $R_{S}(\mathrm{~m})$ is the effective radius of streamline curvature, $\beta_{c}$ is a nondimensional parameter with values between 0 and 1 (taken here as 0.5 ), and $\alpha$ is a nondimensional parameter given by

$$
\alpha=\min \left(\frac{\sqrt{g}}{\kappa C}, \frac{1}{2}\right)
$$

where $\kappa$ is the Von Kármán constant (taken here as 0.4).

[16] Full details of the numerical model set up, together with some preliminary results of the numerical simulations undertaken within the Cecina study reach, have been reported by Mengoni [2004] and Mengoni and Mosselman [2005]. For the purposes of this paper, as previously remarked, we limited our analyses to the first monitoring period, between October and December 2003, which encompasses three flow events (Figure 3) as follows: (1) 1-4 November $2003\left(Q_{\text {peak }}=86.4 \mathrm{~m}^{3} \mathrm{~s}^{-1}\right)$; (2) 24 November to 1 December $2003\left(Q_{\text {peak }}=256.0 \mathrm{~m}^{3} \mathrm{~s}^{-1}\right)$; (3) 29 December 2003 to 1 January $2004\left(Q_{\text {peak }}=59.6 \mathrm{~m}^{3} \mathrm{~s}^{-1}\right)$. The modeled reach (Figure 4) has a length of about $1300 \mathrm{~m}$, a width of 45$150 \mathrm{~m}$, and an average slope of 0.0021 . The relatively large extent of the model domain guarantees the absence of boundary effects in the zone of major interest (the eroding bank indicated by the symbols on Figure 4). The bottom

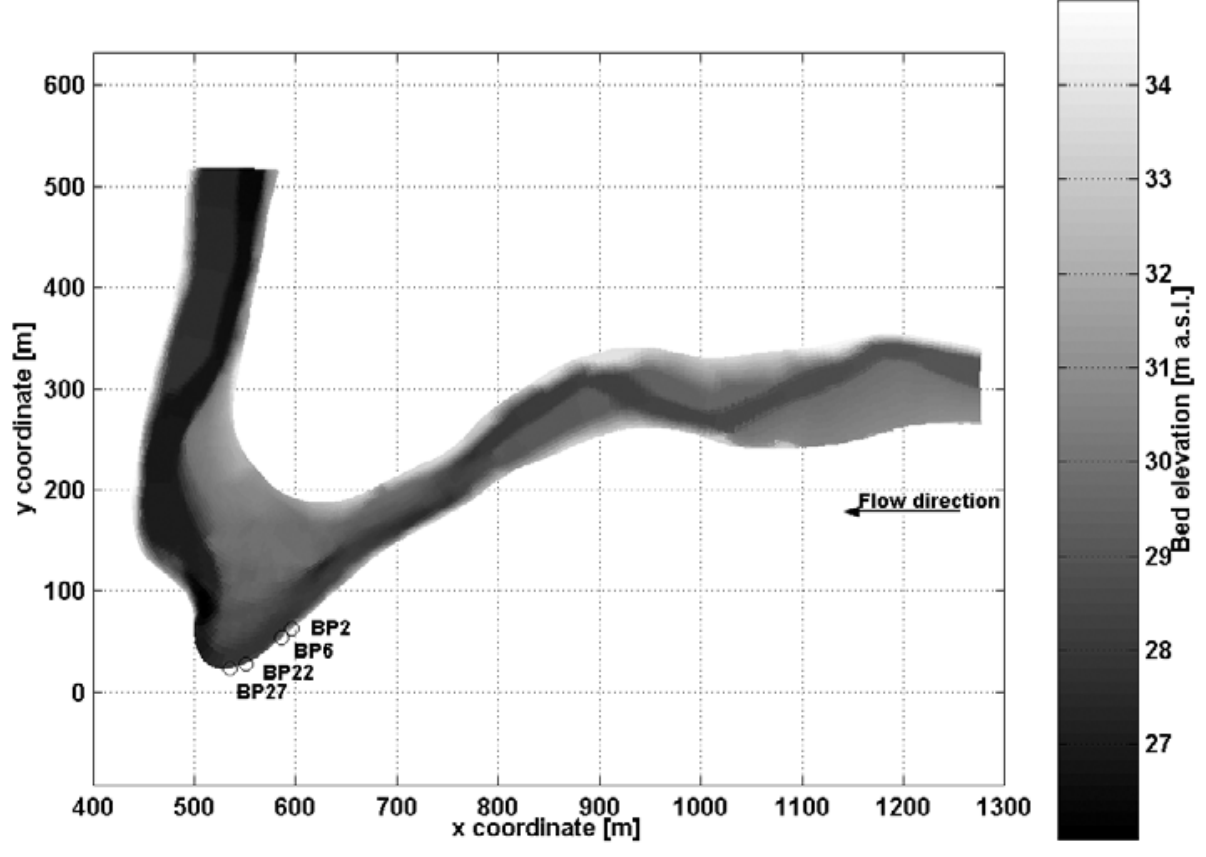

Figure 4. Bed topography of the study reach used for the hydrodynamic simulations, based on the topographic survey carried out during the period March-September 2003, immediately before the start of the monitoring period. BP2, BP6, BP22, and BP27 indicate the position of four representative bank profiles. 
topography was obtained by a detailed topographic survey carried out using a total station during the period MarchSeptember 2003, immediately before the start of the monitoring period. As previously noted, the use of a fixed bed based on this initial bed topography is a potential limitation. However, field observations suggest that only relatively minor net changes in bed topography occurred after the events, suggesting that the fixed bed assumption is in fact reasonable. However, of course this does not exclude the possibility that more significant bed adjustments occur during the flow events. The channel bed was discretized into a numerical grid composed of 11029 grid cells, with 269 in the longitudinal direction and 41 in the transverse direction. The complex planimetric channel shape required the use of variable cell sizes (ranging between $0.5 \mathrm{~m}$ and $4 \mathrm{~m}$ ).

[17] Given that the channel bed is mainly composed of gravel, no bed forms were expected to be found during the simulated flow events, hence roughness was modeled by employing a depth-averaged Chézy coefficient $C_{2-D}$ $\left(\mathrm{m}^{1 / 2} \mathrm{~s}^{-1}\right)$, according to the White-Colebrook formulation:

$$
C_{2 D}=18 \log \left(\frac{12 h}{k_{S}}\right)
$$

where $k_{s}(\mathrm{~m})$ is the Nikuradse roughness length. The modeled area was divided into five different roughness classes: channel bed zone, channel bar zone, vegetated bar zone, bank zone and bank toe zone. For the nonvegetated zone, it was assumed that $k_{s}=3 D_{50}$, considering a variable distribution of sediment sizes based on a series of grain size analyses in the different portions of the channel, whereas for the vegetated zone an average value of $k_{s}$ was calculated employing measured plant height as the local Nikuradse roughness length. The presence of the tributary (Sterza River) was modeled assuming an input of discharge distributed over two grid cells in order to avoid numerical instability. Each event was discretized in a sequence of time steps calculated on the basis of a Courant condition and set equal to $6 \mathrm{~s}$.

[18] The hydrodynamic model requires the definition of boundary conditions along the borders of the numerical grid. They were defined as follows: (1) the total inflow of Cecina River discharge at the upstream boundary cross section; (2) the total inflow of Sterza River discharge at the confluence boundary cross section; and (3) the water level elevation at the downstream boundary cross section. No flow boundary condition is specified along the lateral boundaries, which corresponds to assuming full-slip conditions. This assumption is usually justified in cases where the horizontal dimensions of the computational cells are much larger than the flow depth, so that bed friction dominates over wall friction. Here, however, the horizontal cells have the same order of magnitude as the flow depth. This may result in the boundary shear stress exerted by the flow on the bank being overestimated. In the absence of a more reliable submodel, we accept this error and assume it to be compensated for via the calibration of the erodibility coefficient.

[19] With respect to the inflow boundary conditions, the water discharge at the upstream boundary cross section was assumed equal to the discharge recorded at the gauging station upstream; this is reasonable given that there are no variations in water discharge between the gauging station and the modeled reach due to tributaries or other factors. This inflow discharge was divided over the inlet cross section as a function of water depth (in proportion to $h^{3 / 2}$ in accordance with the Chézy equation). The total inflow of the (ungauged) Sterza River was estimated to be $1 / 6$ of the Cecina discharge, based on the relative drainage areas of the two catchments. Insufficient data are available to define a more reliable hydrological model for the tributary. However, sensitivity analyses indicate that the precise estimate of the tributary inflow has no significant effect either on the general flow pattern or on the shear stress values computed along the eroding bank.

[20] For the downstream boundary condition, a timedependent value of water level was imposed. This water level was obtained by performing a one-dimensional hydraulic simulation using HEC-RAS 3.1.1 [Hydrologic Engineering Center, 2003], the output of that simulation being calibrated by matching (difference of $<0.1 \%$ ) simulated and measured water surface elevations at the location of the river stage sensor installed along the eroding bank. The downstream water level was then extracted from this calibrated profile.

[21] Because of the hazardous nature of the high flow events in the Cecina River, no flow velocity data are available to validate the hydrodynamic model. However, DELFT3D is a widely used software system, and Lesser et al. [2004] have validated its morphological module and all versions of DELFT3D are validated prior to their release using a database comprising 70 cases laboratory experiments and exact analytical solutions. We are therefore confident that our hydrodynamic simulations offer accurate results.

\subsection{Fluvial Erosion Model}

[22] Among the three flow events simulated by the hydrodynamic model, the 24 November to 1 December 2003 flow event was selected for the subsequent bank stability simulations. This was because (1) it was the most important event of the monitoring period, with the highest peak discharge $\left(Q_{\text {peak }}=256.0 \mathrm{~m}^{3} \mathrm{~s}^{-1}\right)$, producing the most significant and relatively homogeneously distributed bank retreat; and (2) the river stage was sufficiently high to reach the upper cohesive portion of the bank, enabling us to investigate the interaction between fluvial erosion and mass failures on this layer of the bank. In contrast, during the other two flow events of the monitoring period, the river stage did not exceed the contact between the basal gravel and the upper cohesive bank. Of the numerous bank profiles, a bank in the more active portion of the eroding reach was selected for the erosion and stability simulation (BP22 in Figure 4). This bank section was deemed representative of the reach as a whole because the retreat observed at this section closely matched the mean rate of the actively eroding reach.

[23] For the purposes of simulating fluvial erosion and bank stability throughout the flow event, the hydrograph was discretized into 27 time steps, based on the original 15-min resolution time series river stage and rainfall data. The temporal resolution of each of these time steps was not uniform (as for the hydrodynamic simulations), but varied in the range from 0.25 to about $50 \mathrm{~h}$, using short time steps 

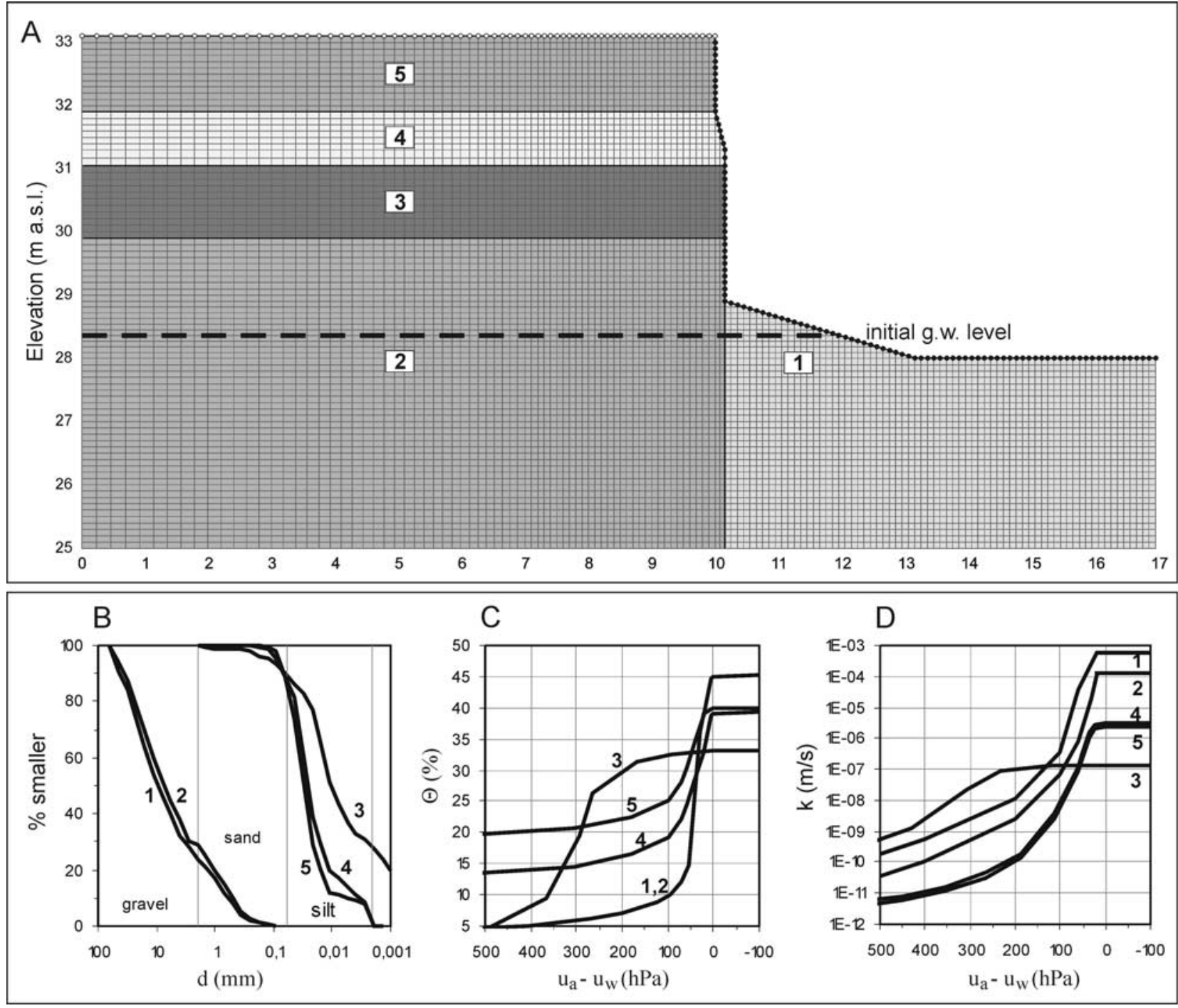

Figure 5. Bank dynamic modeling: finite element groundwater flow model. (a) Geometry of the problem. (b) Grain sizes of the different layers $\left(d=\right.$ diameter). (c) Soil water characteristic curves $\left(u_{a}\right.$ is pore air pressure, $u_{w}$ is pore water pressure, $\theta$ is volumetric water content). (d) Hydraulic conductivity functions ( $k$ is hydraulic conductivity). The location of a piezometer used to calibrate the groundwater flow model (Figure 6) is shown in Figure 5a.

during phases of rapidly varying flow, and longer intervals during phases of relatively constant river stage.

[24] The fluvial erosion rate is quantified using an excess shear stress formula [Partheniades, 1965; Arulanandan et al., 1980] in which

$$
\varepsilon=k_{d}\left(\tau_{b}-\tau_{c}\right)^{a}
$$

where $\varepsilon\left(\mathrm{m} \mathrm{s}^{-1}\right)$ is the fluvial bank erosion rate per unit time and unit bank area, $\tau_{b}(\mathrm{~Pa})$ is the boundary shear stress applied by the flow, $k_{d}\left(\mathrm{~m}^{3}(\mathrm{~N} \mathrm{~s})^{-1}\right)$ is an erodibility coefficient, $\tau_{c}(\mathrm{~Pa})$ is the critical shear stress, and $a$ (dimensionless) is an empirically derived exponent, generally assumed to be equal to 1.0. Boundary shear stresses $\left(\tau_{b}\right)$ required by equation (10) were obtained from the outputs of the hydrodynamic simulations, using values calculated at the nodes closest to the bank toe. Given that the temporal resolution of the hydrodynamic modeling (6s) is much higher than that employed in the fluvial erosion computations, mean values of simulated shear stresses were calculated within each time step used for bank modeling. The fluvial erosion for each time step was then calculated by integrating equation (10) across the interval of the time step, as follows:

$$
\mathrm{LE}=\varepsilon \Delta t=k_{d}\left(\tau_{b}-\tau_{c}\right)^{a} \Delta t
$$

where LE $(\mathrm{m})$ is the lateral erosion per unit bank area and $\Delta t(\mathrm{~s})$ is the time step interval.

[25] Erodibility parameters are highly variable and difficult to estimate. For granular (noncohesive) material, the same methods employed to predict the entrainment of bed material, introducing some modification to account for bank slope [Lane, 1955] and the influence of packing and cementing [e.g., Millar, 2000], are generally used to estimate the critical shear stress, while methods to estimate the 
Table 1. Hydraulic and Geotechnical Parameters Used in the Bank Erosion Modeling ${ }^{\mathrm{a}}$

\begin{tabular}{|c|c|c|c|c|c|c|}
\hline \multirow[b]{2}{*}{ Parameter } & \multicolumn{5}{|c|}{ Sediment Layers } & \multirow[b]{2}{*}{ Notes } \\
\hline & 1 & 2 & 3 & 4 & 5 & \\
\hline $\begin{array}{l}\text { Critical shear stress, } \\
\quad \tau_{c}(\mathrm{~Pa})\end{array}$ & 8.22 & 8.10 & $0.85 \pm 1.04$ & $\mathrm{n} / \mathrm{a}$ & $\mathrm{n} / \mathrm{a}$ & $\begin{array}{l}\text { Values for layer } 3 \text { are the mean and } \\
\text { standard deviation (quoted range) of } \\
\text { three jet tests; see text for layers } \\
1 \text { and } 2\end{array}$ \\
\hline $\begin{array}{l}\text { Erodibility coefficient, } \\
k_{d}\left(\mathrm{~m}^{3}\left(\mathrm{~N} \mathrm{~s}^{-1}\right)\right.\end{array}$ & $\mathrm{n} / \mathrm{a}$ & $6.14 \times 10^{-6}$ & $\begin{array}{l}7.1 \times 10^{-6} \\
\pm 9.06 \times 10^{-7}\end{array}$ & $\mathrm{n} / \mathrm{a}$ & $\mathrm{n} / \mathrm{a}$ & $\begin{array}{l}\text { Values for layer } 3 \text { are the mean and } \\
\text { standard deviation (quoted range) of } \\
\text { three jet tests; see text for layers } \\
1 \text { and } 2\end{array}$ \\
\hline Porosity, $n(\%)$ & 40 & 40 & 33 & 39 & 45 & $\begin{array}{l}\text { Data based on single samples removed } \\
\text { from each layer }\end{array}$ \\
\hline $\begin{array}{l}\text { Saturated hydraulic } \\
\quad \text { conductivity, } k_{\text {sat }}\left(\mathrm{m} \mathrm{s}^{-1}\right)\end{array}$ & $6.0 \times 10^{-4}$ & $1.2 \times 10^{-4}$ & $1.4 \times 10^{-7}$ & $3.2 \times 10^{-6}$ & $2.3 \times 10^{-6}$ & $\begin{array}{l}\text { Values for layers } 4 \text { and } 5 \text { are based on a } \\
\text { single and two Amoozemeter tests, } \\
\text { respectively; see text for details } \\
\text { concerning the other layers }\end{array}$ \\
\hline $\begin{array}{l}\text { Effective cohesion, } \\
c^{\prime}(\mathrm{kPa})\end{array}$ & $\mathrm{n} / \mathrm{a}$ & $\mathrm{n} / \mathrm{a}$ & 4.7 & 3.9 & 3.3 & Data based on a single triaxial test \\
\hline $\begin{array}{l}\text { Effective friction angle, } \\
\phi^{\prime}(\mathrm{deg})\end{array}$ & $\mathrm{n} / \mathrm{a}$ & $\mathrm{n} / \mathrm{a}$ & 32.5 & 35.9 & 37.6 & Data based on a single triaxial test \\
\hline $\begin{array}{l}\text { Matric suction angle, } \\
\phi^{b}(\mathrm{deg})\end{array}$ & $\mathrm{n} / \mathrm{a}$ & $\mathrm{n} / \mathrm{a}$ & $15-32.5$ & $15-35.9$ & $15-37.6$ & See text for explanation \\
\hline $\begin{array}{l}\text { Dry unit weight, } \\
\gamma_{d}\left(\mathrm{kN} / \mathrm{m}^{3}\right)\end{array}$ & $\mathrm{n} / \mathrm{a}$ & $\mathrm{n} / \mathrm{a}$ & 14.9 & 16.4 & 14.6 & $\begin{array}{l}\text { Data based on a single soil sample } \\
\text { for each layer; for bulk unit weight } \\
\text { see text for } \\
\text { explanation }\end{array}$ \\
\hline
\end{tabular}

${ }^{\mathrm{a}}$ Sediment layers are represented in Figure 5; n/a: not applicable.

erodibility parameter $k_{d}$ are not available. For cohesive sediments, in situ jet-testing devices [e.g., Hanson and Simon, 2001] may be used to directly estimate both $k_{d}$ and $\tau_{c}$. In this paper, we have estimated the erodibility parameters using the same methods as detailed by Darby et al. [2007]. These can be summarized for each main bank material as follows:

[26] 1. In the loose gravel method, for the basal wedge of loose gravel $\left(D_{50}=0.013 \mathrm{~m}\right.$, bank angle $\theta=29^{\circ}$; layer 1 in Figure 5a), the critical shear stress was estimated to be $\tau_{c}=8.2 \mathrm{~Pa}$ (see Table 1) using the equation of Lane [1955]. Similar to the work by Darby et al. [2007], we assumed that when $\tau_{c}$ is exceeded, the basal wedge of this material is completely removed and the in situ packed gravel (layer 2 in Figure 5a) starts to be exposed to the direct action of the flow. Furthermore, the model does not predict deposition of loose basal gravel.

[27] 2. In the loose packed gravel method, for the in situ gravel layer $\left(D_{50}=0.011 \mathrm{~m}\right)$, the formula of Millar [2000] has been used, resulting in $\tau_{c}=8.1 \mathrm{~Pa}$ (see Table 1). For this layer, the erodibility coefficient $\left(k_{d}=6.14 \times 10^{-6} \mathrm{~m}^{3}(\mathrm{~N} \mathrm{~s})^{-1}\right.$, see Table 1) was then determined via model calibration (i.e., by forcing best agreement between calculated and measured eroded volumes at the bank toe, see below).

[28] 3. In the loose cohesive sediments method, for the upper cohesive portion of the bank, the only material influenced by the direct action of the flow during the simulated event is layer 3 (see Figure 5a). Consequently a total of three jet tests were performed only for this material, providing mean values of $\tau_{c}$ and $k_{d}$ for this layer as reported in Table 1 .

\subsection{Groundwater Flow Model}

[29] Pore water pressure changes were modeled using $\mathrm{SEEP} / \mathrm{W}$ [Geo-Slope International, 2001a] as in previous studies of riverbank modeling [Rinaldi et al., 2004; Darby et al., 2007]. The model performs a two-dimensional, finite element seepage analysis using the mass conservation equation, in the form extended to unsaturated conditions [Richards, 1931; Fredlund and Rahardjo, 1993]:

$$
\frac{\partial}{\partial x}\left(k_{x} \frac{\partial H}{\partial x}\right)+\frac{\partial}{\partial z}\left(k_{z} \frac{\partial H}{\partial z}\right)+Q=\frac{\partial \theta}{\partial t}
$$

where $H$ is the total head $(\mathrm{m}), k_{x}$ is the hydraulic conductivity in the horizontal $x$ direction $\left(\mathrm{m} \mathrm{s}^{-1}\right), k_{z}$ is the hydraulic conductivity in the vertical $z$ direction $\left(\mathrm{m} \mathrm{s}^{-1}\right), Q$ is the unit flux passing in or out of an elementary cube (in this case an elementary square, given that the equation is in two dimensions) $\left(\mathrm{m}^{2} \mathrm{~m}^{-2} \mathrm{~s}^{-1}\right), \theta$ is the volumetric water content $\left(\mathrm{m}^{3} \mathrm{~m}^{-3}\right)$, and $t$ is time $(\mathrm{s})$. To perform the groundwater flow model, the riverbank was discretized into a series of finite elements, and five regions of different materials were defined to reproduce the observed bank stratigraphy (Figure 5). We employed a regular mesh comprising a total of 8010 elements. We defined basic $0.10 \mathrm{~m}$ square-shaped elements for the region representing the channel bed and for the bank region within $3 \mathrm{~m}$ from the face of the bank profile, whereas elsewhere the elements become rectangular, with an increasing base size up to a maximum of $0.20 \mathrm{~m}$. Elements along the bank profile are triangular, maintaining a base of $0.10 \mathrm{~m}$. The selection of the $0.10 \mathrm{~m}$ sized elements was informed by a series of numerical experiments [Agresti, 2005] in which we compared output data obtained from meshes composed of square elements with dimensions $0.05 \mathrm{~m}, 0.10 \mathrm{~m}$ and $0.20 \mathrm{~m}$, respectively. In comparing the results obtained from each mesh, we considered the differences in the values of pore water pressure and seepage velocity simulated at locations 


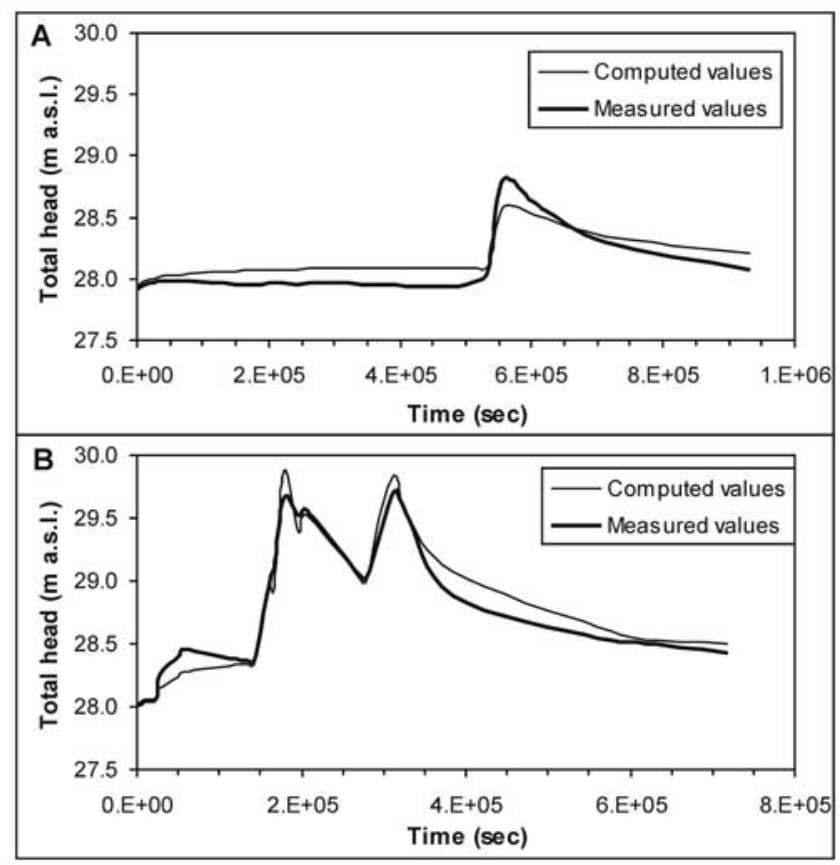

Figure 6. Calibration of the groundwater flow model: computed versus measured values of total head at the piezometer located $3 \mathrm{~m}$ from the bank edge. (a) Flow event $1-4$ November $2003\left(Q_{\text {peak }}=256.0 \mathrm{~m}^{3} \mathrm{~s}^{-1}\right)$. (b) Flow event 24 November to 1 December $2003\left(Q_{\text {peak }}=59.6 \mathrm{~m}^{3} \mathrm{~s}^{-1}\right)$.

along the bank profile and at a distance of $0.8 \mathrm{~m}$ from the bank edge, that is in the region where pore water pressure values are most important in terms of their impact on bank stability. The $0.05 \mathrm{~m}$ resolution mesh generated numerical instabilities and was, therefore, discarded. The $0.10 \mathrm{~m}$ resolution mesh was numerically stable and was, therefore, chosen as the most appropriate.

[30] Application of the groundwater flow model requires a parameterization of the hydraulic and physical properties of the bank sediments (Figure $5 \mathrm{~b}$ and Table 1). This primarily involves the definition, for each type of sediment, of the relations between hydraulic conductivity $(k)$ and pore water pressure $(u)$ (i.e., the hydraulic conductivity function or $k$ curve), and between the volumetric moisture content $(\theta)$ and pore water pressure $(u)$ (i.e., the volumetric water content function or characteristic curve). Accurate parameterization of these relations is important because simulated pore pressures are highly sensitive to these hydraulic functions [Rinaldi et al., 2004]. The $k$ curves and characteristic curves of the different materials were estimated following the procedure described by Rinaldi et al. [2004] and Darby et al. [2007]. In summary, this procedure consists of using a range of empirical relations defined for each type of material [Green and Corey, 1971; Van Genuchten, 1980; Fredlund et al., 1994] based on the grain size distribution of each layer of sediment. Curves already used in previous studies [Rinaldi et al., 2004; Darby et al., 2007] for bank sediments with similar characteristics were also employed. The resulting functions were constrained (by displacing the curves vertically) to match measured values (see Table 1) of porosity $(n)$ and saturated hydraulic conductivity $\left(k_{\text {sat }}\right)$. Porosity was obtained by laboratory analysis of single samples removed from each layer of sediment, whereas for the saturated hydraulic conductivity it was possible to perform in situ Amoozemeter tests [Amoozegar, 1989] only for the most superficial layers 4 and 5. For the remaining layers, saturated conductivity was initially assumed from values reported in the literature for similar material types. A further refinement of the curves (particularly for the layers lacking measurements) was obtained by performing a series of preliminary simulations [Luppi, 2004, 2007], and comparing measured versus calculated pore water pressures at the bank location where the two piezometers were installed (at section 1). Example results of this calibration phase are reported in Figure 6.

[31] The groundwater flow model requires the definition of boundary conditions along the borders of the finite element grid. They were defined as follows: (1) for the nodes along the bank profile (indicated as closed circles in Figure 5a), a total head versus time function was defined using the hydrograph of the event; (2) for the nodes at the top of the bank (indicated as open circles in Figure 5a), a rainfall intensity versus time function was assigned using the time series rainfall data monitored at the gauging station $2 \mathrm{~km}$ upstream; and (3) for the lower horizontal boundary and for the right vertical boundary, a zero flux boundary function was assigned, these regions being always saturated. This follows the argument of Rinaldi et al. [2004] that the zero flux assumption has negligible effects on the pore pressures in the area of interest. For the left vertical boundary, the infinite elements option was preferred to account for possible horizontal saturated and unsaturated fluxes. This option expands the dimensions of the mesh beyond the extent of the defined finite elements by assuming that the soil properties of the bank materials remain invariant over the extended range. Finally, the initial conditions were defined using the groundwater depth measured at the two piezometers installed in the bank (at section 1) before the start of the simulated event.

[32] Deformation of the bank profile to account for fluvial erosion or mass failures during the flow event was achieved by using the same procedure described in detail by Darby et al. [2007]. Summarizing, the finite element mesh adaptation was achieved for each time step of the simulation using two manual procedures: (1) if the rate of fluvial erosion was smaller than the width of the boundary element, the boundary node was shifted horizontally inward by an amount equal to the calculated erosion; and (2) if the fluvial erosion rate was greater than the width of the boundary element, the change in grid geometry was simulated artificially by adjusting (again, manually) the hydraulic conductivity and volumetric water content of eroded cell(s) to replicate the conductivity and saturated state of subaqueous in-channel cells.

[33] In contrast to Darby et al. [2007], where a function describing the distribution of boundary shear stress around the wetted perimeter was used, in this study shear stress values from the hydrodynamic model were used for the wetted bank perimeter. In this way, according to equation (10), the erosion rate was uniform along the wetted portion of the same layer. For the packed gravel (method 2), in case of erosion occurring for a river stage lower than the top of the layer, we assumed that the portion above the river stage was also eroded maintaining a vertical face in this material. 
This is consistent with field observations, given that overhanging portions of the packed gravel were not observed.

\subsection{Bank Stability Model}

[34] Bank stability analysis was performed using the limit equilibrium method. For each time step of the hydrograph, the bank profile geometry (accounting for possible deformation calculated by the fluvial erosion model), and pore water pressure distribution (obtained by the groundwater flow model) were used to perform the stability analysis.

[35] Two specific mechanisms of failure, corresponding to those that were most frequently observed in the field, were simulated: (1) slide-type failure and (2) cantilever failure. For each of the two mechanisms, the factor of safety (FS) was calculated at each time step of the simulation. The SLOPE/W software [Geo-Slope International, 2001b] was used for slide failures. In this software package, the Morgenstern-Price method was preferred to calculate FS, using the Mohr-Coulomb failure criterion in terms of effective stresses for the part of the bank with positive pore water pressures, and the Fredlund et al. [1978] criterion for the unsaturated portion of the bank, the latter being expressed as

$$
\tau=c^{\prime}+\left(\sigma-u_{a}\right) \tan \phi^{\prime}+\left(u_{a}-u\right) \tan \phi^{b}
$$

where $\tau$ is the shear strength $(\mathrm{kPa}), c^{\prime}$ is the effective cohesion $(\mathrm{kPa}), \sigma$ is the normal stress $(\mathrm{kPa}), u_{a}$ is the pore air pressure $(\mathrm{kPa}), \phi^{\prime}$ is the effective friction angle (deg), $u$ is the pore water pressure $(\mathrm{kPa})$, and $\phi^{b}$ is the angle $(\mathrm{deg})$ expressing the rate of increase in strength relative to the matric suction $\left(u_{a}-u\right)$.

[36] For cantilever failures, we analyzed the shear-type failure, which is, according to Thorne and Tovey [1981], the most commonly observed of the three possible mechanisms of cantilever failure. FS used in this analysis is expressed as

$$
F s=\frac{\sum_{i} L_{i} C_{T i}}{\sum \gamma_{i} A_{i}}
$$

where $L_{i}$ is the vertical length (layer $i$ ) of the cantilever block (m), $C_{T i}$ is the total cohesion (layer $i$ ) of the cantilever block $(\mathrm{kPa}), \gamma_{i}$ is the unit weight (layer $i$ ) of the cantilever block $\left(\mathrm{kN} \mathrm{m}^{-3}\right)$, and $A_{i}$ is the cross-sectional area (layer $i$ ) of the cantilever block $\left(\mathrm{m}^{2}\right)$. The effects of negative pore pressures are accounted for in the previous equation, given that the total cohesion is the sum of the effective and apparent cohesion (see equation (13)).

[37] The bank stability analysis was applied only to the upper cohesive portion of the bank (layers 3, 4, and 5), for which the geotechnical properties (i.e., shear strength parameters and unit weight) were required (Table 1). Although recent work [Fox et al., 2007; Wilson et al., 2007] has started to explore the influence of seepage forces on bank stability, for reasons of simplicity we do not consider either the destabilizing effects of seepage forces (due to the hydraulic gradient) or seepage undercutting in this analysis. As such, our stability analysis may potentially overestimate the stability of the modeled stream banks. However, field observations suggest that such processes are not significant at our study site. Undisturbed samples were extracted from the top of the bank by vertical cores (using a Shelby sampler), followed by a single triaxial test for each material and phase relationship analysis. Triaxial tests in saturated conditions allowed for direct determination of the effective cohesion and effective friction angle. Phase relationship analyses included the determination of the specific weight of the sediments, from which the dry unit weight for each unit was determined. The variation of (bulk) unit weight with changing soil water content was accounted for using

$$
\gamma=\gamma_{d}+\rho g \theta
$$

where $\gamma$ is the unit weight of the soil during the time step $\left(\mathrm{N} \mathrm{m}^{-3}\right), \gamma_{d}$ is the unit weight of soil under completely dry conditions $\left(\mathrm{N} \mathrm{m}^{-3}\right)$, and $\theta$ is the volumetric water content $\left(\mathrm{m}^{3} \mathrm{~m}^{-3}\right)$ during the time step, the latter being estimated from the soil water characteristic curve using the simulated pore water pressure in that time step. Note that no adjustments were made to the measured geotechnical properties to account for the presence of vegetation on the surface on the bank (i.e., the effects of vegetation were not considered in our analysis). This is not problematic because the simulated bank profile was, with the exception of some grass (which has negligible biomass and whose roots were very shallow) on the bank top, completely bare.

[38] The matric suction angle $\left(\phi^{b}\right)$ is not constant but varies with matric suction [Fredlund and Rahardjo, 1993]. To account for these variations, a function relating $\phi^{b}$ to the matric suction was defined, based on the soil water characteristic curves, which has the effect of varying $\phi^{b}$ from a minimum value of $15^{\circ}$ to a maximum value equal to $\phi^{\prime}$ when the soil approaches saturation. This follows previous studies [e.g., Fredlund and Rahardjo, 1993; Rinaldi et al., 2004; Darby et al., 2007] in which the failure envelope is divided into a series of linear segments with varying $\phi^{b}$ angles and different intercepts $\left(c^{*}\right)$, each segment corresponding to a range of matric suction.

[39] For slide-type failures, in each time step the most critical failure surface was selected by simulating bank stability for a wide range of trial slip surfaces, the trial surface with the minimum FS being defined as the most critical. In all cases, a tension crack of $0.5 \mathrm{~m}$ depth was included in the upper layer of the bank material, consistent with field evidence. For the cantilever failures, equation (14) was applied every time that a cantilever block was created as a result of fluvial erosion deformation. At the end of each time step, if FS was lower than 1 for one of the two mechanisms, the bank geometry was modified for the following step according to the geometry of the failed block. In case both FS (for slide and cantilever) were lower than 1 , the mechanism with the lowest value was assumed to occur. The failed material was assumed to be completely removed by the flow. This is a reasonable assumption because of the relatively high energy of the river, and in agreement with field observations that reveal only a very limited quantity of fine sediments accumulated at the bank toe after flow events.

\section{Results and Discussion}

\subsection{Hydrodynamic Modeling}

[40] Results derived from the simulations of the three flow events are investigated to elucidate two key aspects: 
(1) the general flow pattern along the entire modeled reach and (2) the magnitudes of the shear stresses exerted along the eroding bank. The main result is that the different flow discharges produce significantly different flow patterns, driven by the planimetric configuration of the study reach. In particular, two flow patterns can be distinguished:

[41] 1. For lower $\left(Q<40 \mathrm{~m}^{3} \mathrm{~s}^{-1}\right)$ flow discharges, the flow is concentrated within the low-water bed and exhibits a sinuous configuration between lateral bars along the straight reaches upstream and downstream of the study bend, whereas the pronounced point bar forces the water to flow adjacent to the eroding bank along the outer part of the bend (upstream of the confluence with the Sterza tributary).

[42] 2. For higher $\left(Q>40 \mathrm{~m}^{3} \mathrm{~s}^{-1}\right)$ flow discharges, the water submerges the entire point bar and the main flow axis shifts to a chute channel across the medial portion of the bar, buffering the eroding bank from the portion of the flow characterized by the highest velocities. A similar outcome (i.e., a reduction of near-bank flow velocity) has been recorded in studies that have highlighted how the main flow can become separated from the channel boundary along the concave (outer) bank of sharply curving river bends [e.g., Hodskinson, 1996; Hodskinson and Ferguson, 1998; Ferguson et al., 2003]. In the case of the Cecina, however, bend curvature decreases as a function of increasing flow stage, and the mechanism of near-bank velocity reduction appears instead to be related to the topographic steering of the flow toward and away from the bank at low and high flow stages, respectively.

[43] We have investigated whether these patterns are in any way an artifact of the presence of the tributary (Sterza River), rather than being forced by the bed topography. Specifically, we conducted simulations (not shown here) in which the tributary was excluded. The results are virtually identical, clearly demonstrating that the presence of the tributary has little impact on the simulated flow patterns and associated hydraulic parameters.

[44] Returning to the details of the 24 November to 1 December flow event, the hydrodynamic simulation (Animation $\mathrm{S} 1$ in the auxiliary material ${ }^{1}$ ) is particularly suitable to visualize the changes in flow patterns that occur during the hydrograph. Figure 7 summarizes the patterns of depth-averaged velocity within the simulated reach at selected time steps of the hydrograph. The following points are evident: at the beginning of the hydrograph $\left(Q=10.2 \mathrm{~m}^{3} \mathrm{~s}^{-1}\right.$, Figure 7a), the flow is concentrated along the outer bank; during the first peak $\left(Q=256.0 \mathrm{~m}^{3} \mathrm{~s}^{-1}\right.$, Figure $\left.7 \mathrm{~b}\right)$, the main flow and highest velocities are displaced to the central part of the point bar; during the minimum between the two peaks $\left(Q=30.6 \mathrm{~m}^{3} \mathrm{~s}^{-1}\right.$, Figure $\left.7 \mathrm{c}\right)$, the pattern is similar to that simulated at the start of the event, albeit with slightly higher velocities; during the second, lower, peak $\left(Q=173.2 \mathrm{~m}^{3} \mathrm{~s}^{-1}\right.$, Figure $\left.7 \mathrm{~d}\right)$, the pattern is again similar to the first peak, but with lower velocities; during the descending phase of the second peak $\left(Q=35.5 \mathrm{~m}^{3} \mathrm{~s}^{-1}\right.$, Figure 7e) and the final part of the hydrograph $\left(Q=10.4 \mathrm{~m}^{3} \mathrm{~s}^{-1}\right.$, Figure $7 \mathrm{f}$ ), the main flow axis returns to the outer bank, with progressively decreasing velocities. During the lower flow phases, the highest velocities are concentrated at the bend

\footnotetext{
${ }^{1}$ Auxiliary materials are available in the HTML. doi:10.1029/ 2008WR007008.
}

apex along the outer bank, slightly downstream of the Sterza confluence, whereas during high flow stages the highest flow velocities occur along the central part of the point bar.

[45] The hydrodynamic model predicts that the shifting of flow starts to occur at a flow discharge of approximately $Q=40 \mathrm{~m}^{3} \mathrm{~s}^{-1}$, when the water starts to be diverted into the secondary chute channel in the central point bar. However, even before this point a progressive reduction of flow velocities along the outer eroding bank is predicted. In fact, during the other two flow events examined here, the peak discharge was not sufficiently high to cause the complete diversion of the flow into the chute channel. Even so, a progressive reduction of velocities and shear stresses with increasing flow discharge (up to the $Q=40 \mathrm{~m}^{3} \mathrm{~s}^{-1}$ threshold) was predicted along the eroding bank.

[46] Regarding the shear stresses simulated along the eroding bank, our simulations show that they are quite variable, depending on the specific spatial position along the bank. According to the bank retreat monitoring (Figure 2), two different portions of the eroding bank can be distinguished: a more stable upstream part (about the first $30 \mathrm{~m}$ ), and a more rapidly eroding downstream part (the remaining $50 \mathrm{~m}$ ). An effective way to visualize the differences in nearbank flow parameters at these locations is to plot the shear stress values obtained for the full range of simulated discharges (Figure 8). This was done at sites corresponding to bank profiles representative of the upstream (BP2 and BP6) and downstream (BP22 and BP27) portions of the bank, respectively (see Figure 4 for the locations of these bank profiles). It is apparent from Figure 8 that (1) near bank shear stresses are lower in the upstream portion of the reach and (2) the peak shear stresses tend to increase downstream, reaching a maximum (notably larger than for the other locations) at the last bank profiles (BP27), close to the tributary confluence. A summary of the results associated with the most critical conditions for the selected bank profiles is also reported in Table 2.

[47] Returning to the details of the second (24 November to 1 December) flow event, it is also interesting to report the variations of near-bank shear stress across the flow hydrograph, again at the same two eroding bank locations. Figure 9 emphasizes how the near-bank shear stresses are out of phase with the river stage during the hydrograph, with negligible shear stresses during the peak phases, but higher values during the ascending and descending phases. This trend is more pronounced for the downstream, more unstable, portion of the bank and has important implications for the bank dynamics, as discussed in section 4.2.

\subsection{Bank Dynamics Modeling}

[48] Bank changes during the 24 November to 1 December 2003 flow event were modeled for two scenarios, in order to better understand the importance of fluvial erosion in inducing mass failures:

[49] 1. The bank profile is not deformed by fluvial erosion, but it is modified to account for the changing geometry after mass failures.

[50] 2. The bank profile is deformed both by fluvial erosion and mass failures.

[51] Comparisons between calculated and measured bank profiles for the two scenarios are illustrated in Figure 10. For scenario 1 , the predicted volume eroded by mass failure is 

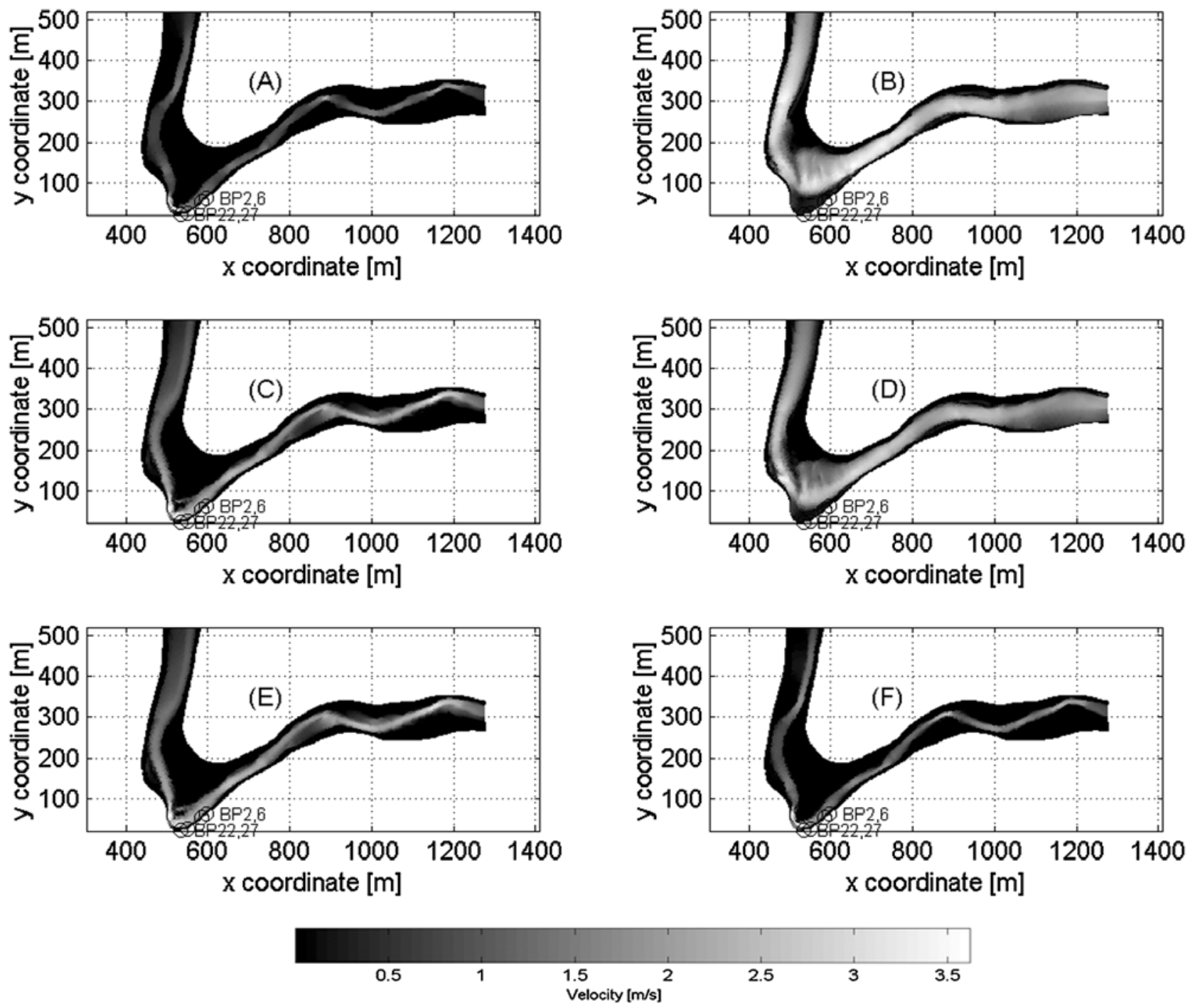

Figure 7. Results of hydrodynamic modeling for the 24 November to 1 December 2003 flow event $\left(Q_{\text {peak }}=256.0 \mathrm{~m}^{3} \mathrm{~s}^{-1}\right)$ : depth-averaged flow velocity. (a) At the start of the hydrograph $\left(\mathrm{Q}=10.2 \mathrm{~m}^{3} \mathrm{~s}^{-1}\right)$; (b) first peak $\left(\mathrm{Q}=256.0 \mathrm{~m}^{3} \mathrm{~s}^{-1}\right)$; (c) minimum between the two peaks $\left(\mathrm{Q}=30.6 \mathrm{~m}^{3} \mathrm{~s}^{-1}\right)$; (d) second peak $\left(\mathrm{Q}=173.2 \mathrm{~m}^{3} \mathrm{~s}^{-1}\right)$; (e) descending phase after the second peak $\left(\mathrm{Q}=35.5 \mathrm{~m}^{3} \mathrm{~s}^{-1}\right)$ (corresponding to the time step when fluvial erosion occurred); (f) final part of the hydrograph $\left(\mathrm{Q}=10.42 \mathrm{~m}^{3} \mathrm{~s}^{-1}\right)$. BP 2 , 6 and BP 22, 27 indicate the position of four representative bank profiles (BP).

$2.11 \mathrm{~m}^{3} \mathrm{~m}^{-1}$, compared to the measured value of $2.73 \mathrm{~m}^{3} \mathrm{~m}^{-1}$, an underestimate of $0.62 \mathrm{~m}^{3} \mathrm{~m}^{-1}(23 \%$ error $)$. The resulting error in the position of the bank top is about $20 \mathrm{~cm}$. Fluvial erosion is not predicted in scenario 1, therefore the total predicted volume of eroded sediments remains $2.11 \mathrm{~m}^{3} \mathrm{~m}^{-1}$, versus a total measured eroded volume of $3.75 \mathrm{~m}^{3} \mathrm{~m}^{-1}$, a much larger underestimate of $1.64 \mathrm{~m}^{3} \mathrm{~m}^{-1}$ (44\% error).

[52] For scenario 2, the model still underestimates the volume eroded by mass failure $\left(2.47 \mathrm{~m}^{3} \mathrm{~m}^{-1}\right)$, but the error decreases to a value of only $0.26 \mathrm{~m}^{3} \mathrm{~m}^{-1}$ (about $10 \%$ error), while the position of the top of the bank is correctly predicted. It should be noted that the model does not predict the deposition of loose basal gravel, so the predicted profile at the bank toe has to be compared with the measured profile of the packed gravel. In this case there is close agreement between the predicted $\left(1.04 \mathrm{~m}^{3} \mathrm{~m}^{-1}\right)$ and mea- sured $\left(1.02 \mathrm{~m}^{3} \mathrm{~m}^{-1}\right)$ eroded volumes, though this is simply due to the fact that the erodibility parameter of the packed gravel was calibrated by forcing optimal agreement between these volumes. For the bank as a whole, the total predicted volume of eroded sediments $\left(3.51 \mathrm{~m}^{3} \mathrm{~m}^{-1}\right)$ is in error only by a small amount $\left(0.24 \mathrm{~m}^{3} \mathrm{~m}^{-1}\right.$, a $6 \%$ relative error $)$.

[53] Time series of factor of safety, with respect to slide and cantilever failure mechanisms, and of volumes of eroded sediment contributed by fluvial erosion and mass failures were then produced and compared for the two scenarios (Figure 11). In terms of the bank stability response the simulated flow events can, for the purposes of discussion, be divided into 4 phases (Figures 11a and 11c): (1) the first (minor) peak; (2) the second (major) peak; (3) a third (intermediate) peak; and, (4) the drawdown phase. 


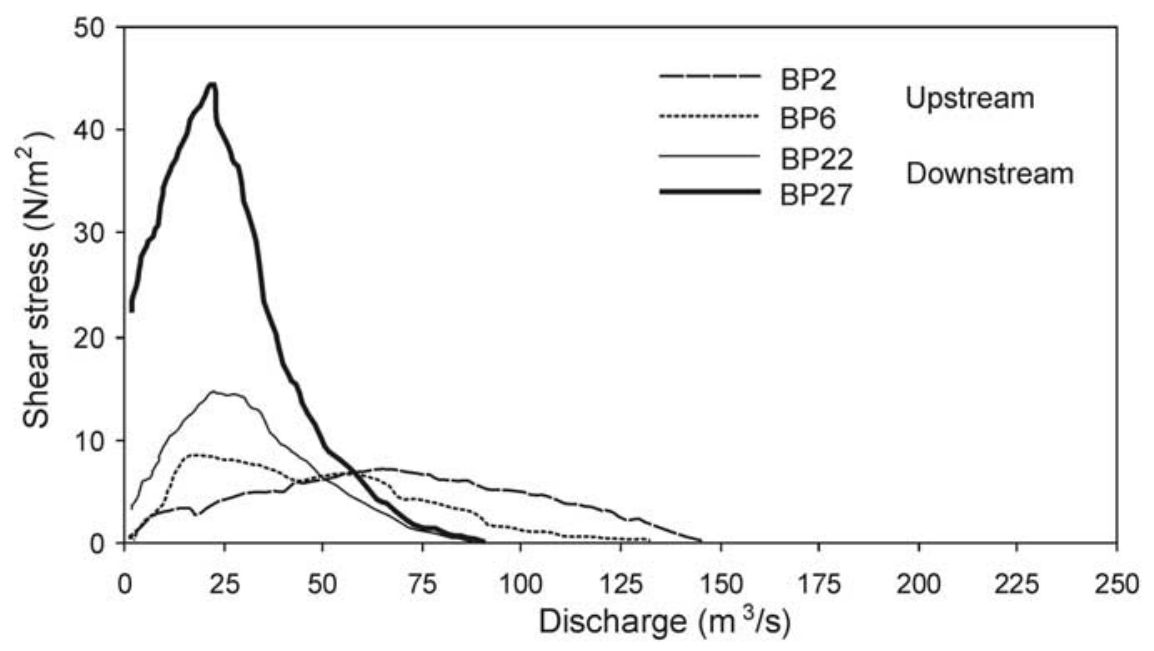

Figure 8. Results of hydrodynamic modeling: near-bank shear stress versus flow discharge derived for four representative bank profiles (BP) located at the upstream and downstream limits of the eroding bank (the location of these bank profiles is shown in Figure 4).

\subsubsection{Scenario 1: No Fluvial Erosion}

[54] At the beginning of the event, FS with respect to slide-type failure is significantly higher than the critical value of 1 (1.5), decreasing only slightly to a minimum value of 1.42 during the first phase of the hydrograph, because pore water pressure changes are minor at this stage. However, during the rising phase of the main peak (second phase), there is an initial reduction in FS, reaching limit equilibrium conditions with values close to 1 (1.11), before remaining roughly constant during the remainder of this phase. A further slight reduction occurs at the moment of the inversion from the drawdown to the rising phase of the hydrograph (step 21 after $82.5 \mathrm{~h}$, at the beginning of phase 3 ), triggering the onset of a slide failure $(F s=0.82)$. FS then increases abruptly to a value of 1.50 , as a result of the new stable bank profile. During the final drawdown (phase 4), FS again decreases, approaching limit equilibrium conditions (values ranging from 1.07 to 1.10), as a result of relatively high pore water pressures and the absence of confining pressures, but no new failures occur until the end of the event. In this scenario note that cantilever failures are not analyzed because cantilever blocks are never generated in the absence of fluvial erosion. In summary, when there is no deformation by fluvial erosion this event is characterized by a single failure (slide) occurring at the passage from the end of the main peak drawdown and the onset of the

Table 2. Summary of Near-Bank Hydraulic Parameters at Four Representative Bank Profiles Associated With the Maximum Predicted Shear Stress ${ }^{\mathrm{a}}$

\begin{tabular}{llccc}
\hline$B P$ & $\tau_{\max }(\mathrm{Pa})$ & $Q\left(\mathrm{~m}^{3} / \mathrm{s}\right)$ & $\hat{U}(\mathrm{~m} / \mathrm{s})$ & $C_{2 D}$ \\
\hline 2 & 7.2 & 65.8 & 1.14 & 13.50 \\
6 & 8.8 & 16.8 & 1.05 & 11.22 \\
22 & 15.0 & 22.4 & 1.53 & 12.45 \\
27 & 45.7 & 22.9 & 2.53 & 11.83 \\
\hline
\end{tabular}

${ }^{\text {a }}$ Profile locations are shown in Figure 4; $\tau_{\max }$, maximum near-bank shear stress calculated at the bank toe grid cell; $Q$, associated discharge; $\hat{U}$, magnitude of depth averaged flow velocity vector $\left(\hat{U}=\sqrt{U^{2}+V^{2}}\right.$, where $U$ and $V$ are the depth-averaged velocity components in the $x$ and $y$ directions, respectively); $C_{2 D}$, associated Chézy coefficient $\left(\mathrm{m}^{1 / 2} \mathrm{~s}^{-1}\right)$. following rising phase. The failed block has a substantial size, delivering a relatively high volume $\left(2.11 \mathrm{~m}^{3} \mathrm{~m}^{-1}\right)$ of bank sediment to the river.

[55] This result is consistent with previous bank stability simulations that take no account of fluvial erosion [Casagli et al., 1999; Simon et al., 2000; Dapporto et al., 2003; Rinaldi et al., 2004; Darby et al., 2007], where a single failure (slide) often occurs during the initial drawdown phase. In previous studies the drawdown phase has often therefore been identified as the most critical phase in terms

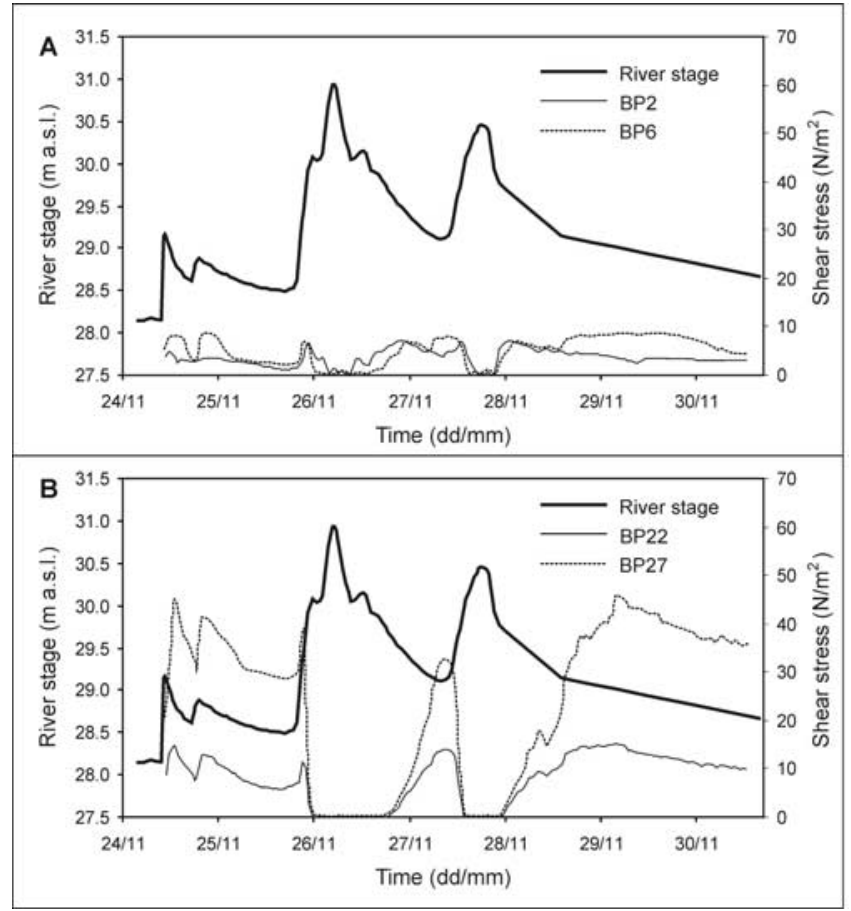

Figure 9. Results of hydrodynamic modeling: variations of near-bank shear stresses during the 24 November to 1 December 2003 flow event $\left(Q_{\text {peak }}=256.0 \mathrm{~m}^{3} \mathrm{~s}^{-1}\right)$ at representative bank profiles (BP) located at the (a) upstream and (b) downstream limits of the eroding bank. 


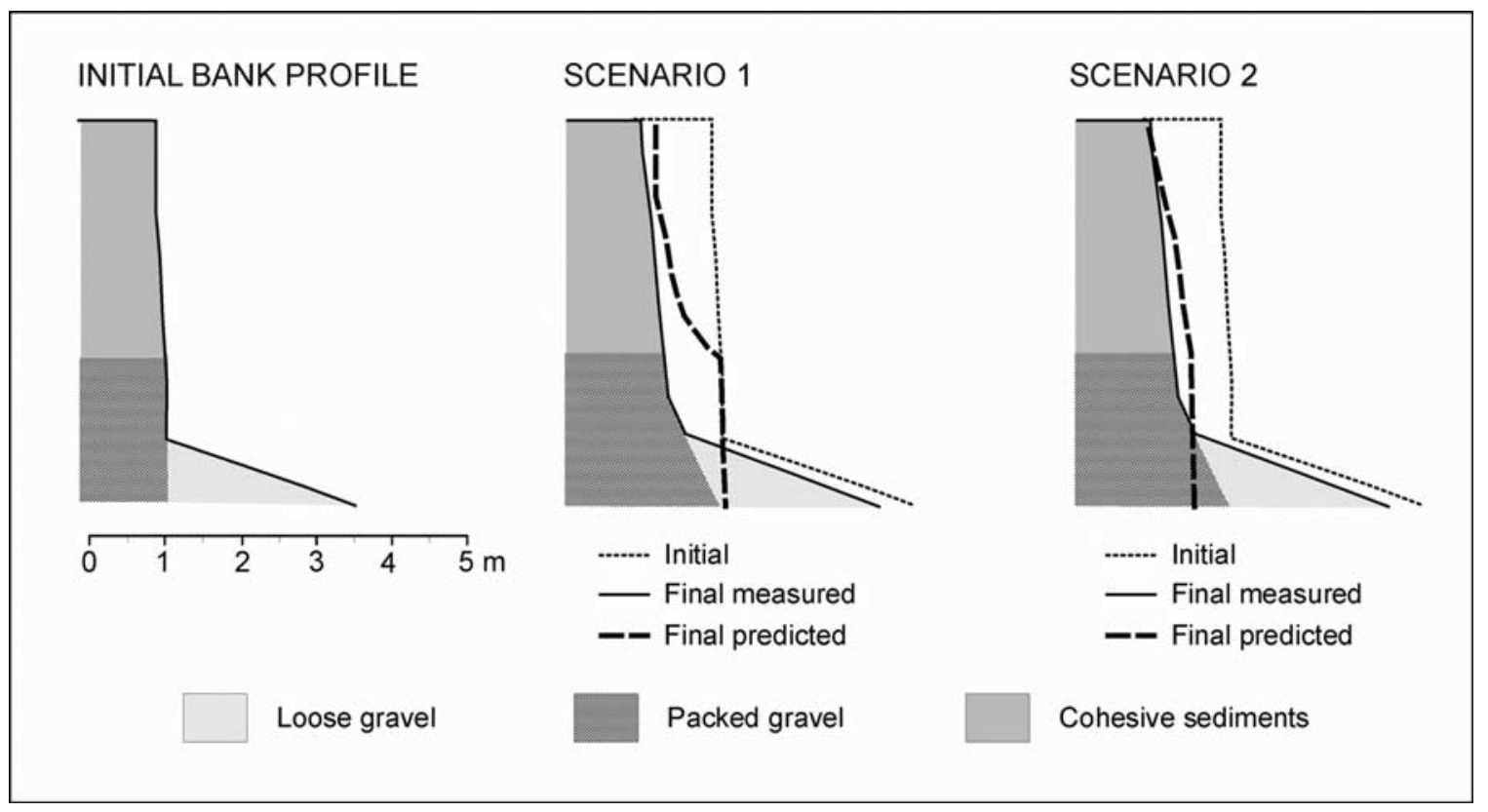

Figure 10. Comparison of predicted and observed bank changes at bank profile 22 for the two simulated scenarios during the 24 November to 1 December 2003 flow event $\left(Q_{\text {peak }}=256.0 \mathrm{~m}^{3} \mathrm{~s}^{-1}\right)$.

of bank stability, due to the increased saturation, involving a significant length of the failure surface, being combined with the loss of confining pressure due to the rapid drawdown of river stage [Rinaldi et al., 2004].

\subsubsection{Scenario 2: Interacting Fluvial Erosion and Mass Failures}

[56] Similar to the hydrodynamic modeling, animated graphics of the bank dynamic simulation (Animation S2) provide the best means of visualizing the effects of the interacting processes. For this simulation, deformation of the bank profile due to fluvial erosion was achieved for each time step by manually updating the bank geometry in the groundwater flow and bank stability models.

[57] During phase 1, the trend of the simulated FS is identical to that in scenario 1 , and is also very similar during phase 2, though in this latter case with slightly lower values. This is due to the fact that in this scenario the loose basal gravel is eroded (during time step 4), when the critical shear stress for this material is exceeded. This causes slightly higher pore water pressures due to the direct contact of the river with the packed gravel. The packed gravel is eroded at time steps 5 and 7, causing only a very small amount of bank retreat and sediment volume $\left(0.08 \mathrm{~m}^{3} \mathrm{~m}^{-1}\right)$. Subsequently, fluvial erosion does not occur during the ascending phase and the main peak of the event, due to the diversion of flow across the point bar and consequent reduction in shear stresses as described previously. A more important erosive period occurs between time steps 18 and $20\left(0.44 \mathrm{~m}^{3} \mathrm{~m}^{-1}\right)$, during the drawdown phase that follows the main peak. This modifies the bank profile, creating a cantilever, but FS with respect to this mechanism remains higher than 1. Contrarily, a slide failure occurs at time step 21, as in the previous scenario, but with a further lower FS (0.76), as a result of the less favorable geometry. The geometry and volume $\left(2.15 \mathrm{~m}^{3} \mathrm{~m}^{-1}\right)$ of the failed block are also very similar to the scenario without fluvial erosion. Differently from the previous scenario, however, in this case the bank profile is not yet stable after the failure. In fact, two small slides occur during the following two time steps, further adjusting the bank profile along layer 3 , but producing a limited additional volume of sediments $\left(0.64 \mathrm{~m}^{3} \mathrm{~m}^{-1}\right.$ in total $)$. This phase of high instability is also strictly related to unfavorable pore water pressure conditions: during the rising phase of the third peak, groundwater levels exceed the river stage, indicating an inversion of the seepage flow (from the bank toward the river). After this sequence of slides, FS increases considerably to a value of 1.6 , and then continues to increase during the first part of the drawdown phase up to a maximum value of 2.53. During time step 24, a new phase of fluvial erosion occurs $\left(0.52 \mathrm{~m}^{3} \mathrm{~m}^{-1}\right)$, as a result of the high shear stresses during the redirection of the flow back to the outer bank. This causes a new reduction in the stability of the upper cohesive portion of the bank and consequently a decrease of FS, but values remain higher than 1 so no new mass failure episode occurs.

[58] It is evident that the scenario with bank deformation by both fluvial erosion and mass failures exhibits a much more complex interaction between the two types of processes, with a sequence of erosive phases and failures, that is not predictable by a classical analysis (scenario 1) that does not allow the two processes to interact [Darby et al., 2007]. It is also clear that the simulated fluvial erosion is quite intermittent, not at all like the quasi-continuous process often referred to in the literature [Thorne, 1982; Darby and Thorne, 1996; Lawler et al., 1997]. At this study site, these discontinuous phases of fluvial erosion are related to the complex temporal pattern of near-bank shear stress, which in turn is related to the characteristics of the flow event and to the specific geometrical and topographical characteristics of the study bend.

[59] The difference in the volume of bank material eroded by mass failures $\left(2.47 \mathrm{~m}^{3} \mathrm{~m}^{-1}\right.$ in scenario 2 compared to $2.11 \mathrm{~m}^{3} \mathrm{~m}^{-1}$ for the single failure in scenario 1$)$, is not very large $(17 \%)$. However, when the volume eroded by fluvial 

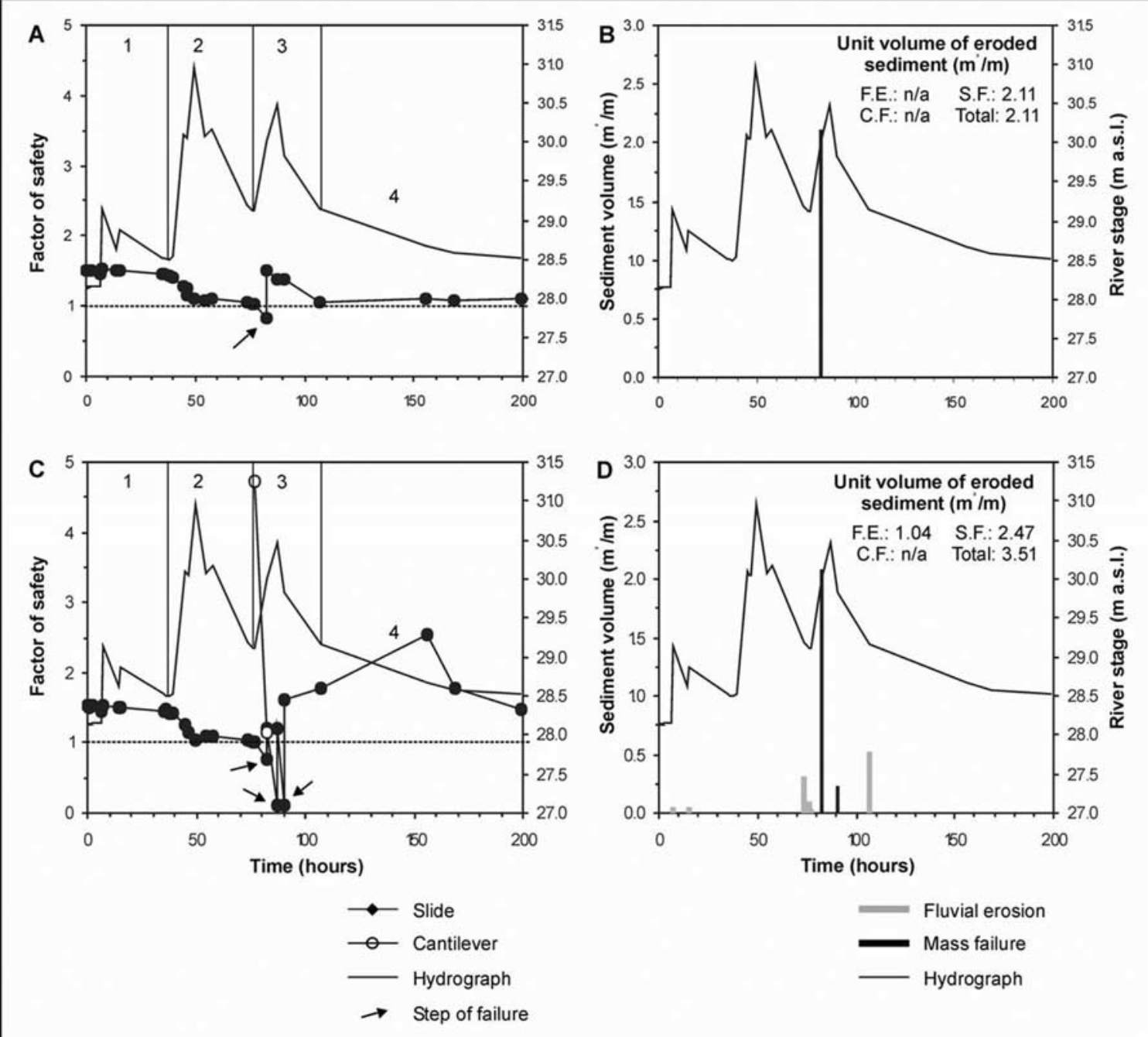

Figure 11. Results of bank erosion modeling for the 24 November to 1 December 2003 flow event $\left(Q_{\text {peak }}=256.0 \mathrm{~m}^{3} \mathrm{~s}^{-1}\right)$. Scenario 1 (no bank deformation by fluvial erosion): (a) Trend of FS for slide failure; (b) eroded volumes of bank sediment. Scenario 2 (bank deformation by fluvial erosion): (c) Trends of FS for slide and cantilever failure; (d) eroded volumes of bank sediment. The event hydrograph is also shown (solid lines). The dotted horizontal lines indicate the critical FS value of unity ( $F_{S}<1$ implies bank collapse), with the arrows indicating the onset of simulated failure episodes. Note that FS data for the cantilever failures are plotted only for those points in time when a cantilevered (overhanging) bank profile is actually present. The 1-4 in Figures 11a and 11c indicate the phases of the flow hydrograph: 1, first peak; 2, second peak; 3, third peak; 4, drawdown. F.E., fluvial erosion; C.F., cantilever failure; S.F., slide failure.

erosion $\left(1.04 \mathrm{~m}^{3} \mathrm{~m}^{-1}\right)$ is considered, erosion volumes in the two scenarios differ by a more substantial $66 \%$. It is clear that mass failures are the dominant process in terms of contributing volumes of eroded material, accounting for $70 \%$ of the total. This is in part due to the bank geometry at the study site, which is characterized by a dominant portion of cohesive material (about $63 \%$ of the total bank height). However, fluvial erosion, as expected, plays an important role in the bank dynamics. Changes in bank geometry due to fluvial erosion are not decisive in triggering mass failure, given that the slide also occurs in the scenario with no fluvial deformation at the same step. However, fluvial erosion causes an increased number of failures and their timing within the event hydrograph also differs, such that the magnitude and frequencies of bank sediment delivery to the bank toe is significantly different between the two scenarios [Darby et al., 2007].

[60] In order to better visualize the contrasting trends of fluvial erosion and mass failure in relation to the flow hydrograph, we have plotted the trends of the key parameters for the two processes, shear stresses and pore water pressures respectively (Figure 12). For the groundwater level, a vertical located a distance of $1 \mathrm{~m}$ from the bank top was chosen as sufficiently representative to display the pore water pressure trends, while the near-bank shear stresses obtained from the hydrodynamic modeling and used for the fluvial erosion model are shown in the same graph. It is evident how the groundwater level is perfectly in phase with river stage. Generally, the groundwater level is lower than the river level (i.e., the seepage flow is directed 


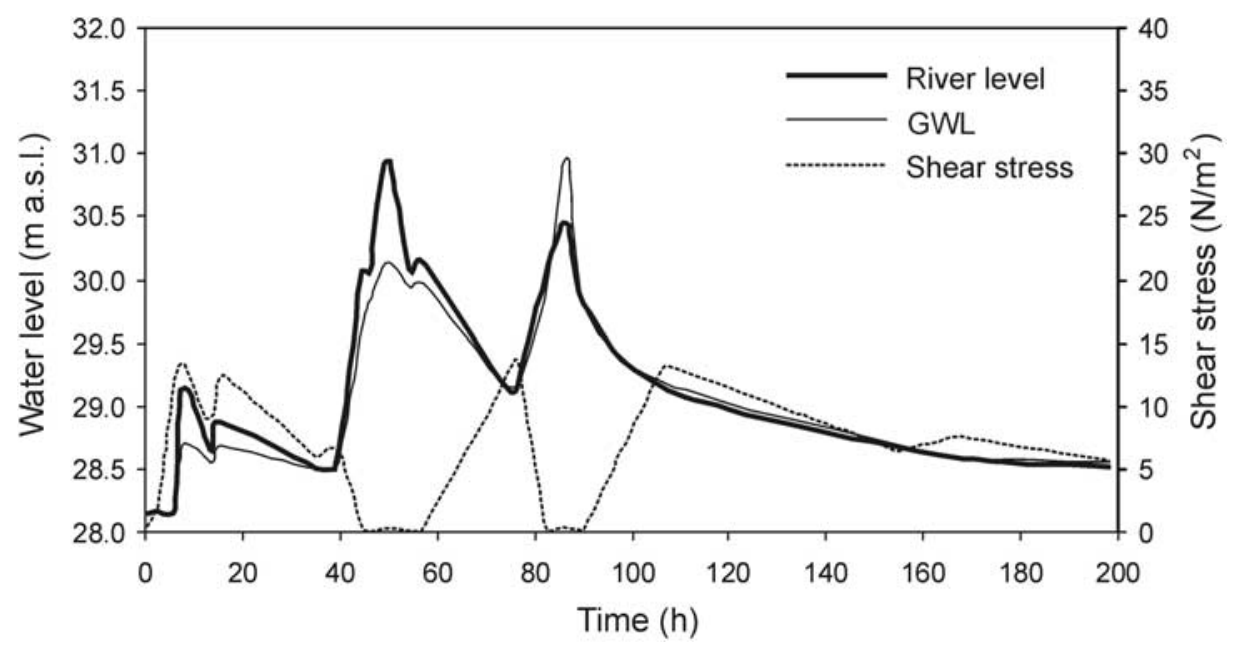

Figure 12. Results of bank erosion modeling for the 24 November to 1 December 2003 flow event $\left(Q_{\text {peak }}=256.0 \mathrm{~m}^{3} \mathrm{~s}^{-1}\right)$ : flow hydrograph, changes in groundwater level $(\mathrm{GWL})$, near-bank shear stresses, and occurrence of erosive processes. GWL, groundwater level; F.E., fluvial erosion; M.F., mass failure; $\tau_{c}$, critical shear stress for the packed gravel at the bank toe.

from the river toward the bank), except during the inversion from a drawdown to a subsequent rising phase, when groundwater and river stage are about equal, and during the third peak, when groundwater exceeds the river stage. These phases are therefore unfavorable in terms of the balance between pore water and confining pressures. Furthermore, during the third peak an inversion of seepage flow direction occurs. This can be particularly important in terms of the potential occurrence of seepage erosion, focused within bank layers of relatively high soil conductivity, which may then promote further bank failures [Fox et al., 2007; Wilson et al., 2007], although seepage erosion is not explicitly quantified in our model.

[61] In contrast to the groundwater levels, the near-bank shear stresses are out of phase with the river stage, as discussed previously. The critical moments for fluvial erosion are during the drawdown phases, not the peak flow stages as might be expected. In a multipeak event such as that simulated in this study, the concomitance of unfavorable pore water pressures and shear stresses occurs, therefore, between the late drawdown of the peak flow phases, when shear stresses are high, and the beginning of the rising phase of the following peak, when the groundwater level becomes equal or sometimes higher than the river stage. This appears to be a particularly effective combination of factors determining instability conditions, at least for the hydrograph characteristics and channel geometry analyzed in this specific case study. Rinaldi et al. [2004] have also shown that multipeak flow events, characterized by secondary peaks preceding the main one, are more destabilizing than flow events with a single, distinct rising phase. However, their results were based on simulations with no fluvial erosion, only accounting for the geotechnical factors. The results of this study suggest that, at least in channel bends with the topographical characteristics of this study case, destabilizing hydraulic factors (high shear stresses) can further promote bank instability during multipeak events, superimposing their effects in phase with unfavorable pore water and confining pressure conditions. More case studies and flow events need to be analyzed to determine how these trends can be applied more generally.

\section{Conclusions}

[62] This study presents the first attempt to fully couple hydrodynamic and riverbank dynamic models. The simulations demonstrate a series of complexities and unexpected trends that only come to light as a result of using this approach. It has to be remarked that the results of the simulations presented in this paper are, of course, limited to the particular sedimentary and morphological conditions of the Cecina riverbank and channel bend and are focused on a single hydrograph. Although our findings are not transferable to different conditions, they do allow us to make hypotheses and to define the possible implications that require further study in a wider range of situations. The main conclusions from this case study can be summarized as follows:

[63] 1. This study identifies two mechanisms that may offer an explanation for the common observation that most bank retreat usually occurs after, rather than during, the peak of a flood. The first mechanism relates to our finding that, for bends of pronounced curvature, the highest flow discharges result in a movement of the core of maximum flow velocity away from the outer bank, thereby reducing sidewall boundary shear stress and fluvial erosion at the peak flow stages. The second mechanism relates to our findings that bank failure episodes are triggered by unfavorable combinations of pore water and hydrostatic confining pressures induced in the period between the drawdown and rising phases of multipeaked flow events. Both of these mechanisms are summarized in further detail in the following points.

[64] 2. Simulated near-bank shear stresses are seen to be out of phase with the river stage, with the highest shear stress occurring during lower flows, instead of at the times of peak flow stages. This is due to the complex relationship between flow discharge and bank shear stress induced by the specific geometric configuration of the channel bend, 
which induces a shifting of the main flow along a chute channel in the central part of the point bar during high flows $\left(Q>40 \mathrm{~m}^{3} \mathrm{~s}^{-1}\right)$, thereby causing a reduction in near-bank shear stress.

[65] 3. Bank modeling reveals a complex interaction between fluvial erosion and mass failures, with the most unstable conditions occurring during the period between the drawdown and initial rising of a subsequent peak, due to the concomitance of high shear stresses and unfavorable pore water and confining pressures. Conversely, peak flow stages do not appear to be critical in terms of inducing episodes of bank instability.

[66] 4. Comparisons of simulations for two scenarios (with and without deformation by fluvial erosion) provide insights into the relevance of fluvial erosion in contributing to bank retreat. In the scenario with no deformation, mass failure occurs by a single, relatively large, slide. The total volume of eroded bank sediments for scenario 2 (fluvial erosion and mass failures) is about $66 \%$ higher than for scenario 1 (mass failures only). Moreover, this additional eroded material is delivered to the channel at different points in time within the event hydrograph, such that the magnitude and frequencies of bank sediment delivery episodes differs significantly between the two scenarios. In scenario 2, the sequence of slide failures (one larger and two small) occurs during the rising phase of the third peak; however, fluvial erosion that occurs during the subsequent descending phase is responsible for removing the failed material from the bank toe.

[67] 5. In our simulations, fluvial erosion appears to be an intermittent process similar to mass failure, with erosive phases concentrated in particular time steps rather than being continuous during the hydrograph. In terms of its quantitative contribution to the total bank retreat, fluvial erosion is less important than mass failure, being responsible for about $30 \%$ of the total amount of bank retreat. However, the role of fluvial erosion in interacting with mass failures and determining the final bank geometry is nevertheless extremely important.

[68] Acknowledgments. This research was supported by the Royal Society (Joint Project grant 15077) and by the project "Monitoraggio e modellazione dei processi di erosione di sponde fluviali" (2002/04) (Fondo Ateneo ex $60 \%$, Università di Firenze). The following are also acknowledged for giving their support at different stages of the research: L. B. Teruggi, S. Dapporto, F. Vannacci, F. Canovaro, L. Nardi, F. Agresti, and L. Coppi (University of Florence), as well as B. Jagers (WL | Delft Hydraulics/Deltares). Furthermore, F. Mansella, E. Di Carlo, and B. Mazzanti of the National Hydrographic Survey of Pisa and Florence are acknowledged for providing hydrological data. We would also like to thank three anonymous referees for their constructive reviews.

\section{References}

Agresti, F. (2005), Modellamento dei processi di arretramento di una sponda del Fiume Cecina, M. S. thesis, 353 pp., Univ. di Firenze, Florence, Italy.

Amoozegar, A. (1989), A compact constant-head permeameter for measuring saturated hydraulic conductivity of the vadose zone, Soil Sci. Soc. Am. J., 53, 1356-1361.

Arulanandan, K., E. Gillogley, and R. Tully (1980), Development of a quantitative method to predict critical shear stress and rate of erosion of natural undisturbed cohesive soils, Rep. GL-80-5, U. S. Army Corps of Eng., Waterways Exp. Stn., Vicksburg, Miss.

Bull, L. J. (1997), Magnitude and variation in the contribution of bank erosion to the suspended sediment load of the River Severn, UK, Earth Surf. Processes Landforms, 22, 1109-1124, doi:10.1002/(SICI)10969837(199712)22:12<1109::AID-ESP810>3.0.CO;2-O.
Casagli, N., M. Rinaldi, A. Gargini, and A. Curini (1999), Pore water pressure and streambank stability: Results from a monitoring site on the Sieve River, Italy, Earth Surf. Processes Landforms, 24, $1095-$ 1114, doi:10.1002/(SICI)1096-9837(199911)24:12<1095::AIDESP37>3.0.CO;2-F.

Clark, L. A., and T. M. Wynn (2007), Methods for determining streambank critical shear stress and soil erodibility: Implications for erosion rate predictions, Trans. Am. Soc. Agric. Biol. Eng., 50, 95-106.

Dapporto, S., M. Rinaldi, N. Casagli, and P. Vannocci (2003), Mechanisms of riverbank failure along the Arno River, central Italy, Earth Surf. Processes Landforms, 28, 1303-1323, doi:10.1002/esp.550.

Darby, S. E., and C. R. Thorne (1996), Development and testing of riverbank stability analysis, J. Hydraul. Eng., 122(8), 443-454, doi:10.1061/ (ASCE)0733-9429(1996)122:8(443).

Darby, S. E., M. Spyropoulos, N. Bressloff, and M. Rinaldi (2004), Fluvial bank erosion in meanders: A CFD modelling approach, in Aquatic Habitats: Analysis and Restoration, vol. 1, edited by D. Garcia de Jalon Lastra and P. V. Martinez, pp. 268-273, Int. Assoc. of Hydraul. Eng. and Res., Madrid, Spain.

Darby, S. E., M. Rinaldi, and S. Dapporto (2007), Coupled simulations for fluvial erosion and mass wasting for cohesive river banks, J. Geophys. Res., 112, F03022, doi:10.1029/2006JF000722.

Ferguson, R. I., D. R. Parsons, S. N. Lane, and R. J. Hardy (2003), Flow in meander bends with recirculation at the inner bank, Water Resour. Res., 39(11), 1322, doi:10.1029/2003WR001965.

Fox, G. A., G. V. Wilson, R. Periketi, and F. F. Cullum (2006), Sediment transport model for seepage erosion of streambank sediment, J. Hydrol. Eng., 11(6), 603-611, doi:10.1061/(ASCE)1084-0699(2006)11:6 (603).

Fox, G. A., G. V. Wilson, A. Simon, E. Langendoen, O. Akay, and J. W. Fuchs (2007), Measuring streambank erosion due to ground water seepage: Correlation to bank pore water pressure, precipitation, and stream stage, Earth Surf. Processes Landforms, 32(10), 1558-1573, doi:10.1002/ esp. 1490 .

Fredlund, D. G., and H. Rahardjo (1993), Soil Mechanics for Unsaturated Soils, John Wiley, New York.

Fredlund, D. G., N. R. Morgenstern, and R. A. Widger (1978), The shear strength of unsaturated soils, Can. Geotech. J., 15(3), 313-321, doi: $10.1139 /$ t78-029.

Fredlund, D. G., A. Xing, and S. Huang (1994), Predicting the permeability function for unsaturated soils using the soil-water characteristic curve, Can. Geotech. J., 31, 533-546, doi:10.1139/t94-062.

Geo-Slope International (2001a), SEEP/W for finite element seepage analysis, version 5, user manual, Calgary, Alberta, Canada.

Geo-Slope International (2001b), SLOPE/W for slope stability analysis, version 5, user manual, Calgary, Alberta, Canada.

Goodson, J. M., A. M. Gurnell, P. G. Angold, and I. P. Morrissey (2002), Riparian seed banks along the lower River Dove UK, Geomorphology, 47, 45-60, doi:10.1016/S0169-555X(02)00140-X.

Green, R. E., and J. C. Corey (1971), Calculation of hydraulic conductivity: A further evaluation of some predictive methods, Soil Sci. Soc. Am. Proc., 35, 3-8.

Hanson, G. J., and A. Simon (2001), Erodibility of cohesive streambeds in the loess area of the midwestern USA, Hydrol. Processes, 15, 23-38, doi:10.1002/hyp.149.

Hodskinson, A. (1996), Computational fluid dynamics as a tool for investigating separated flow in river bends, Earth Surf. Processes Landforms, 21, 993-1000, doi:10.1002/(SICI)1096-9837(199611)21:11<993::AIDESP698>3.0.CO;2-R.

Hodskinson, A., and R. I. Ferguson (1998), Numerical modelling of separated flow in river bends: Model testing and experimental investigation of geometric controls on the extent of flow separation at the concave bank, Hydrol. Processes, 12, 1323-1338, doi:10.1002/(SICI)10991085(19980630)12:8<1323::AID-HYP617>3.0.CO;2-S.

Hydrologic Engineering Center (2003), HEC-RAS, version 3.1.1, U. S. Army Corps of Eng., Davids, Calif.

Julian, J. P., and R. Torres (2006), Hydraulic erosion of cohesive riverbanks, Geomorphology, 76, 193-206, doi:10.1016/j.geomorph.2005. 11.003.

Kean, J. W., and J. D. Smith (2006a), Form drag in rivers due to small-scale natural topographic features: 1. Regular sequences, J. Geophys. Res., 111, F04009, doi:10.1029/2006JF000467.

Kean, J. W., and J. D. Smith (2006b), Form drag in rivers due to small-scale natural topographic features: 2. Irregular sequences, J. Geophys. Res., 111, F04010, doi:10.1029/2006JF000490.

Lane, E. W. (1955), Design of stable channels, Trans. Am. Soc. Civ. Eng., $120,1234-1260$. 
Lawler, D. M. (1993), The measurement of river bank erosion and lateral channel change, Earth Surf. Processes Landforms, 18, 777-821, doi:10.1002/esp.3290180905.

Lawler, D. M., C. R. Thorne, and J. M. Hooke (1997), Bank erosion and instability, in Applied Fluvial Geomorphology for River Engineering and Management, edited by C. R. Thorne et al., pp. 137-172, John Wiley, Chichester, U. K.

Lesser, G. R., J. A. Roelvink, J. A. T. M. Van Kester, and G. S. Stelling (2004), Development and validation of a three-dimensional morphological model, Coastal Eng., 51(8-9), 883-915, doi:10.1016/j.coastaleng.2004.07.014.

Luppi, L. (2004), Monitoraggio e modellazione del rapporto fiume-falda ed effetti sulla stabilità di una sponda del Fiume Cecina, M. S. thesis, 167 pp., Univ. di Firenze, Florence, Italy.

Luppi, L. (2007), Studio dei processi di erosione di sponde fluviali e influenza della vegetazione riparia sulla stabilità, Ph.D. thesis, 213 pp., Univ. di Firenze, Florence, Italy.

Luppi, L., M. Rinaldi, B. Teruggi, E. Darby, and L. Nardi (2008), Monitoring and numerical modelling of riverbank erosion processes: A case study along the Cecina River (central Italy), Earth Surf. Processes Landforms, in press.

McBride, M., W. C. Hession, D. M. Rizzo, and D. M. Thompson (2007), The influence of riparian vegetation on near-bank turbulence: A flume experiment, Earth Surf. Processes Landforms, 32(13), 2019-2037, doi:10.1002/esp.1513.

Mengoni, B. (2004), River width adjustments: Large-scale and local-scale approaches, Ph.D. thesis, Univ. of Florence, Florence, Italy.

Mengoni, B., and E. Mosselman (2005), Analysis of river bank erosion processes: Cecina river, Italy, in Proceedings of the 4th Conference on River, Coastal and Estuarine Morphodynamics, RCEM 2005, edited by G. Parker and M. Garcia, pp. 943-951, Taylor and Francis Group, London.

Millar, R. G. (2000), Influence of bank vegetation on alluvial channel patterns, Water Resour. Res., 36, 1109-1118, doi:10.1029/1999WR900346.

Papanicolaou, A. N., M. Elhakeem, and R. Hilldale (2007), Secondary current effects on cohesive river bank erosion, Water Resour. Res., 43, W12418, doi:10.1029/2006WR005763.

Partheniades, E. (1965), Erosion and deposition of cohesive soils, J. Hydraul. Div. Am. Soc. Civ. Eng., 91, 105-139.

Pollen, N. (2006), Temporal and spatial variability of root reinforcement of streambanks: Accounting for soil shear strength and moisture, Catena, 69, 197-205, doi:10.1016/j.catena.2006.05.004.

Pollen, N., and A. Simon (2005), Estimating the mechanical effects of riparian vegetation on streambank stability using a fiber bundle model, Water Resour. Res., 41, W07025, doi:10.1029/2004WR003801.

Reneau, S. L., P. G. Drakos, D. Katzman, D. V. Malmon, E. V. McDonald, and R. T. Ryti (2004), Geomorphic controls on contaminant distribution along an ephemeral stream, Earth Surf. Processes Landforms, 29, 12091223, doi:10.1002/esp.1085.

Richards, L. A. (1931), Capillary conduction of liquid through porous medium, J. Phys., 1, 318-333, doi:10.1063/1.1745010.

Rinaldi, M., and S. E. Darby (2008), Modelling river-bank-erosion processes and mass failure mechanisms: Progress towards fully coupled simulations, in Gravel-Bed Rivers 6-From Process Understanding to River Restoration, Dev. Earth Surf. Processes, vol. 11, edited by H. Habersack et al., pp. 213-239, Elsevier, New York.

Rinaldi, M., N. Casagli, S. Dapporto, and A. Gargini (2004), Monitoring and modeling of pore water pressure changes and riverbank stability during flow events, Earth Surf. Processes Landforms, 29, 237-254, doi:10.1002/esp. 1042 .

Simon, A. (1995), Adjustment and recovery of unstable alluvial channels: Identification and approaches for engineering management, Earth Surf. Processes Landforms, 20, 611-628, doi:10.1002/esp.3290200705.

Simon, A., and A. J. Collison (2002), Quantifying the mechanical and hydrological effects of vegetation on streambank stability, Earth Surf. Processes Landforms, 27, 527-546, doi:10.1002/esp.325.

Simon, A., A. Curini, S. E. Darby, and E. J. Langendoen (2000), Bank and near-bank processes in an incised channel, Geomorphology, 35, 193218, doi:10.1016/S0169-555X(00)00036-2.

Simon, A., E. J. Langendoen, A. Collison, and A. Layzell (2003), Incorporating bank-toe erosion by hydraulic shear into a bank-stability model: Missouri River, Eastern Montana, in World Water and Environmental Resources Congress and Related Symposia [CD ROM], edited by P. Bizier and P. De Barry, Am. Soc. of Civ. Eng., Philadelphia, Pa.

Simon, A., N. L. Pollen, and E. J. Langendoen (2006), Influence of two woody riparian species on critical conditions for streambank stability: Upper Truckee River, California, J. Am. Water Resour. Assoc., 42, 99113, doi:10.1111/j.1752-1688.2006.tb03826.x.

Thorne, C. R. (1982), Processes and mechanisms of river bank erosion, in Gravel-Bed Rivers, edited by R. D. Hey et al., pp. 227-271, John Wiley, Chichester, U. K.

Thorne, C. R., and N. K. Tovey (1981), Stability of composite river banks, Earth Surf. Processes Landforms, 6, 469-484, doi:10.1002/ esp.3290060507.

Tolhurst, T. J., K. S. Black, S. A. Shayler, S. Mather, I. Black, K. Baker, and D. M. Paterson (1999), Measuring the in situ erosion shear strength of intertidal sediments with the Cohesive Strength Meter (CSM), Estuarine Coastal Shelf Sci., 49, 281-294, doi:10.1006/ecss.1999.0512.

Van De Wiel, M. J., and S. E. Darby (2007), A new model to analyse the impact of woody riparian vegetation on the geotechnical stability of riverbanks, Earth Surf. Processes Landforms, 32, 2185-2198, doi:10.1002/esp.1522.

Van Genuchten, M. T. (1980), A closed-form equation for predicting the hydraulic conductivity of unsaturated soils, Soil. Sci. Soc. Am. J., 44, 892-898.

Wilson, G. V., R. K. Periketi, G. A. Fox, S. M. Dabney, F. D. Shields, and R. F. Cullum (2007), Seepage erosion properties contributing to streambank failure, Earth Surf. Processes Landforms, 32(3), 447-459, doi:10.1002/esp.1405.

WL | Delft Hydraulics (2006), Delft3D-FLOW: Simulation of multidimensional hydrodynamic flows and transport phenomena, including sediments, user manual, Delft, Netherlands.

Wynn, T., and S. Mostaghimi (2006), The effects of vegetation and soil type on streambank erosion, southwestern Virginia, USA, J. Am. Water Resour. Assoc., 42(1), 69-82, doi:10.1111/j.1752-1688.2006.tb03824.x.

S. E. Darby, School of Geography, University of Southampton, Highfield, Southampton SO17 1BJ, UK.

L. Luppi and M. Rinaldi, Department of Civil and Environmental Engineering, University of Florence, via S. Marta 3, I-50139 Florence, Italy. (mrinaldi@dicea.unifi.it)

B. Mengoni, CERAFRI, Retignano di Stazzema (LU), I-55040, Italy.

E. Mosselman, Deltares and Delft University of Technology, Delft, NL-2600 MH, Netherlands. 